\title{
Orthogonal protection of peptides and peptoids for cyclization by the thiol-ene reaction and conjugation
}

Xavier Elduque, Enrique Pedroso and Anna Grandas*

Departament de Química Orgànica i IBUB, Facultat de Química, Universitat de Barcelona, Martí i Franquès 1-11, 08028 Barcelona, Spain

anna.grandas@ub.edu

\section{Abstract/TOC graphic}

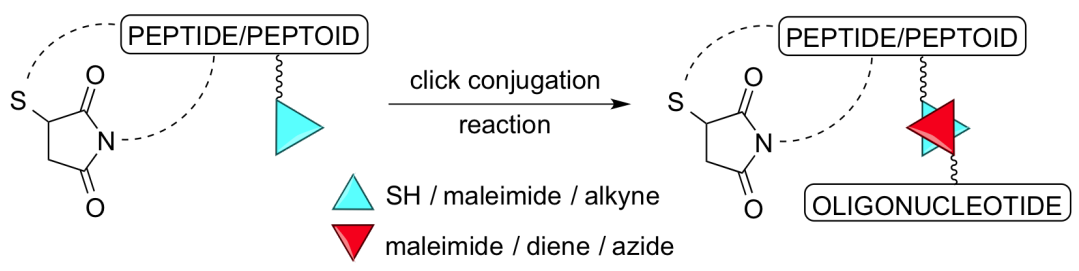

\begin{abstract}
Cyclic peptides and peptoids were prepared using the thiol-ene Michael-type reaction. The linear precursors were provided with additional functional groups allowing for subsequent conjugation: an orthogonally protected thiol, a protected maleimide, or an alkyne. The functional group for conjugation was placed either within the cycle or in an external position. The click reactions employed for conjugation with suitably derivatized nucleoside or oligonucleotides were either cycloadditions (Diels-Alder, $\mathrm{Cu}(\mathrm{I})$-catalyzed azide-alkyne) or the same Michael-type reaction as for cyclization.
\end{abstract}




\section{INTRODUCTION}

With respect to the linear counterparts, conformationally constrained peptides offer increased bioavailability and affinity for the target. ${ }^{1}$ Cell uptake has been shown to increase if cyclization is accompanied by the formation of internal H-bonds, which reduces the cost of amide bond desolvation. ${ }^{2,3}$ Suitably derivatized cyclic peptides can be used as scaffolds (cyclic decapeptide $\mathrm{RAFT}^{4}$ is an example) for the assembly of different moieties (epitopes, drugs, ligands, labels, etc.) at predetermined positions, affording biomolecules with a degree of structural organization much higher than the one accessible through derivatization of a linear peptide. Furthermore, cyclic peptides hold promise to interfere with protein-protein or protein-RNA interactions (references 5-7 are some examples of recent publications on these subjects).

A survey of the latest literature shows that the synthesis of conjugates of cyclic peptides is an active subject of research. In a large number of papers the affinity of $\alpha_{V} \beta_{3}$ integrin $^{8}$ for RGD-containing cyclic peptides ${ }^{9}$ (RGD = ArgGlyAsp) is exploited to develop new methodologies both for the selective targeting and the imaging of tumor cells/tissues and vessels expressing that cell adhesion protein. Additionally, conjugates of cyclic peptides with biological interest (immunosuppressive, epitope mimicking, antimicrobial, antifungal, or cell penetrating, among others) or nanotube precursors have been prepared to improve pharmacological properties ${ }^{10-15}$ and to investigate new materials. $^{16,17}$

Amide-linked units form most of these peptides, while some incorporate unnatural linkages. As to the conjugation chemistry, formation of peptide bonds and the Michaeltype reaction between a maleimide and a thiol are the most common alternatives, but other "click" reactions, and particularly the $\mathrm{Cu}(\mathrm{I})$-catalyzed azide-alkyne cycloaddition, are becoming increasingly frequent. 
There are very few reports on the synthesis and application of [cyclic peptide]oligonucleotide conjugates. Hamilton and coworkers ${ }^{18}$ linked cyclic tetrapeptides to guanine-rich oligonucleotides that assembled onto a parallel tetraplex. The distribution of the peptide ligands on the vertexes of the top tetrad provided an $\alpha$-chymotrypsin inhibitor that effectively interacted with the protein surface. In a related approach, the covalent attachment of peptides to the $5^{\prime}$ ends of two guanine-rich oligonucleotides provided, in the presence of potassium cations, a parallel G-quadruplex with two loop mimics on its surface. ${ }^{19}$ Cyclic peptides have been covalently linked to the sense strand of a siRNA duplex, which facilitated transport of the oligonucleotide through the cell membrane and inhibited gene expression. ${ }^{20}$ More recently, disulfide-containing citrullinated peptides have been linked to various oligonucleotides and immobilized on plates for diagnostic ELISA assays. ${ }^{21}$

In this manuscript we wish to describe methodology allowing for the straightforward synthesis of [cyclic peptide]-oligonucleotide conjugates. Model peptides (and a peptoid) cyclized using the Michael-type maleimide-thiol reaction ${ }^{22}$ and incorporating a functional group allowing for subsequent conjugation were prepared. Then, oligonucleotides were linked to different positions (internal or external) of the cyclic polyamide using various click reactions, namely the Diels-Alder and $\mathrm{Cu}(\mathrm{I})$-catalyzed Huisgen cycloadditions, or, again, the Michael-type thiol-ene. We believe that easy access to [cyclic peptide]-oligonucleotide conjugates will pave the way for new studies aiming at assessing whether cyclic peptides facilitate the cell uptake of oligonucleotides, and promote interactions with cell machineries different from those driven by the linear oligomers. To our knowledge, whether the gene silencing or spliceswitching properties of oligonucleotides linked to cyclic peptides differ from those of [linear peptide]-oligonucleotide conjugates has never been assessed. 


\section{RESULTS}

As recently described by the group, ${ }^{22}$ peptides can be cyclized by reaction between a maleimide and a thiol. Cyclic peptides can be obtained from linear precursors after the TFA treatment that deprotects the peptide chain following stepwise elongation on a solid matrix, using $S$-trityl protected cysteine and a maleimide moiety (Scheme 1A). Since the maleimide moiety is labile to nucleophiles such as piperidine, which is used at every synthesis cycle to remove the Fmoc temporary protecting group, it can only be installed at the $N$-terminus. For introduction at any other position of the chain the maleimide has to be protected, for which purpose an Fmoc-lysine derivative with 2,5dimethylfuran-protected 3-maleimido-propanoic acid linked to the $\varepsilon$-amine can be used. ${ }^{23}$ In this case the cyclic peptide is not obtained after the reaction with TFA but after the thermal treatment that deprotects the maleimide.

Cyclic peptides can be derivatized for conjugation in three different ways (see Scheme 1B). In cyclic peptides types I and II, the functional group for conjugation (depicted as a triangle) is outside the cycle, and the cycle involves, respectively, amino acids placed at either the $N$-terminus of the peptide chain (the group for conjugation is then placed at the $C$-terminus) or the $\mathrm{C}$-terminus (and the group for conjugation is at the $N$-terminus). In type III cyclic peptides the group for conjugation is within the cycle.

Linear precursors incorporating a free and a protected maleimide are needed to synthesize maleimido-derivatized cyclic peptides. The free maleimide, which will form the cycle, can only be placed at the $\mathrm{N}$-terminal end, while the protected moiety can occupy any other position. As stated above, if the protected maleimide is closer to the $C$-terminus than the thiol involved in cyclization, the result is a type $\mathbf{I}$ cyclic peptide 
(Scheme 1C, alternative a). These peptides can be conjugated with either thiol- or dienederivatized molecules.
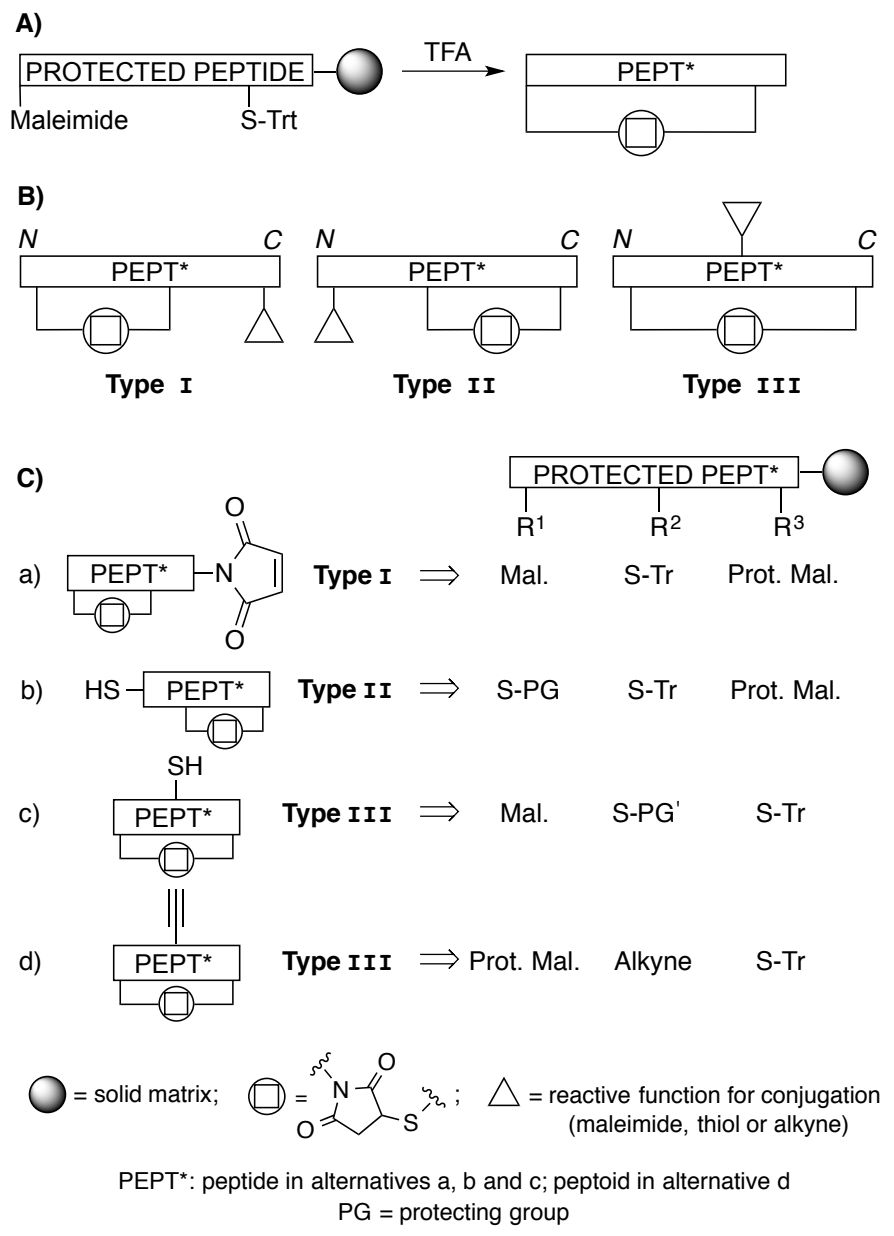

Scheme 1. A) General procedure for the synthesis of peptides cyclized using the thiolmaleimide reaction. B) General structure of the three types of cyclic peptides (or peptoid) prepared in this work, derivatized for conjugation. Cyclization was accomplished by a Michaeltype maleimide-thiol reaction in all cases. C) Schematic structure of the cyclic molecules showing the functional group for conjugation, and combinations of functional groups $\left(\mathrm{R}^{1}, \mathrm{R}^{2}\right.$ and $\mathrm{R}^{3}$, suitably protected when required) on the resin-linked peptide/peptoid precursor for each of the alternatives tested (a-d). Two of those groups had to react with each other and generate the cycle, and the third provided the functionality for conjugation with another molecule (in this work, nucleoside or oligonucleotide). Their relative position within the chain determined the 
type of cyclic molecule that was obtained (I, II or III). Abbreviations: Fm = 9-fluorenylmethyl; Mal. $=$ maleimide; Prot. mal. $=(2,5$-dimethylfuran $)$-protected maleimide; $\operatorname{Tr}=$ trityl.

The precursors of cyclic peptides derivatized with thiols must incorporate two orthogonally protected cysteine residues. The cysteine residue involved in cyclization can be protected with the trityl group (Scheme 1C, alternatives b and c), but the best option to protect the cysteine residue involved in conjugation depends on its position within the chain (see below). Both thiol-derivatized cyclic peptides types II and III have been prepared, and conjugated with a maleimido-containing compound.

The use of different reactions for cyclization and conjugation is less complicated from the chemical point of view, and has been evaluated with a peptoid chain (peptoid units are $N$-alkylglycines). Even though the thiol-ene reaction is probably much quicker than the reduction of azides by thiols, ${ }^{24,25}$ we preferred not to expose the azide to the presence of a free thiol. Hence, an azide-containing molecule was used for conjugation with the alkyne-derivatized, type III cyclic peptide. Cyclization can be carried out with no risk in the presence of an alkyne (Scheme 1C, alternative d), which will not react with either the thiol or the maleimide.

Peptides were prepared by solid-phase synthesis using the standard Fmoc/t Bu methodology. All were assembled on the Rink amide MBHA ( $p$ methylbenzhydrylamine) resin, and were thus obtained as $C$-terminal carboxamides.

Acylation with 3-maleimidopropanoic acid after chain elongation allowed a free maleimide to be attached to the peptide $N$-terminus.

These compounds were conjugated with suitably derivatized oligonucleotides (or nucleoside), as shown in Schemes 2-5 in more detail. Diene- and maleimido-containing oligonucleotides ( $\mathrm{dT}_{5}, \mathrm{dT}=2$ '-deoxythymidine) were synthesized following described procedures. $^{26,27}$ 
Schemes 2, 3 and 4 illustrate in more detail the different steps required to obtain cyclic peptides types I to III, and the corresponding conjugation products.

\section{Synthesis and conjugation of a type I cyclic peptide}

In the first alternative (aimed to provide type I cyclic peptide, a in Scheme 1B), the fully protected peptide precursor (1) incorporated two maleimides, one free (at the $\mathrm{N}$ terminus) and one protected (at the $C$-terminus), and a trityl-protected cysteine residue (Scheme 2). Therefore, the TFA treatment that was carried out after assembly of the linear precursor removed all protecting groups except that on the $C$-terminal maleimide, and, as previously described, ${ }^{22}$ furnished the partially protected cyclic peptide 2 . Maleimide thermal deprotection (retro-Diels-Alder reaction) was performed subsequently in the presence of 5'-diene- $\mathrm{dT}_{5}$, which afforded the target conjugate 3.

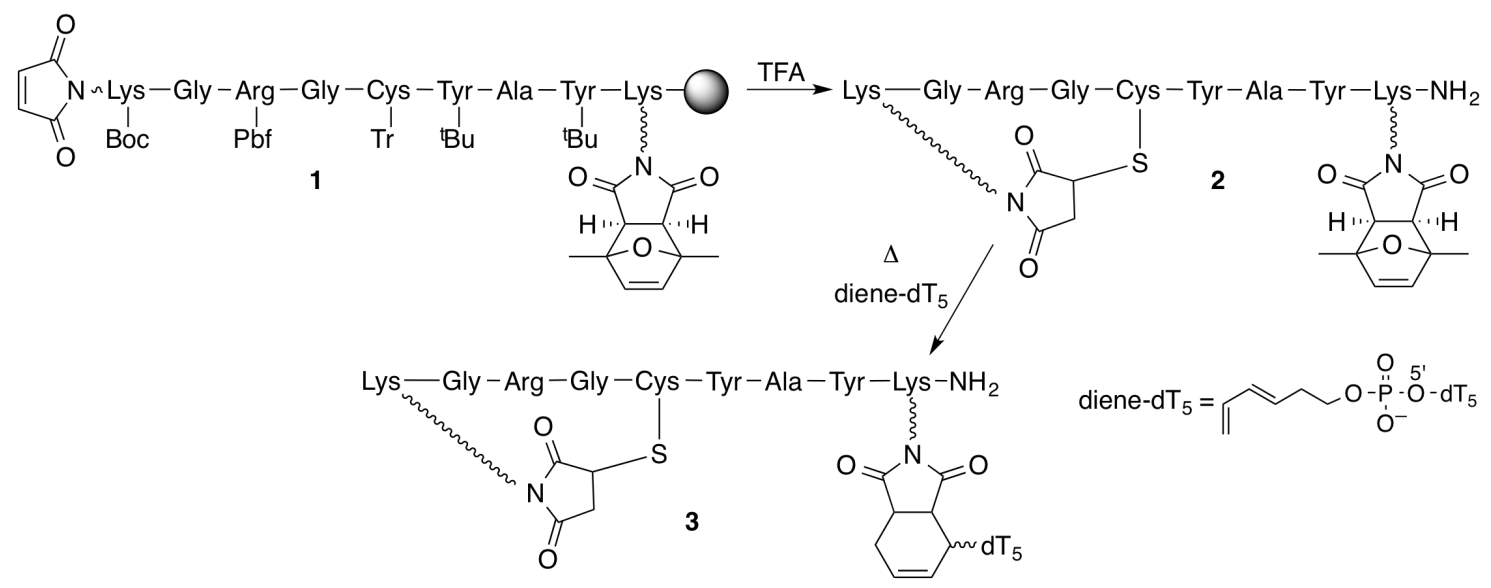

Scheme 2. Synthesis of type I cyclic peptide 2 and conjugation with oligonucleotide $\mathrm{dT}_{5}$. Abbreviations: $\mathrm{Pbf}=2,2,4,6,7$-pentamethyldihydro-benzofuran-5-sulfonyl.

\section{Synthesis and conjugation of a type II cyclic peptide}

The goal of the second alternative (b in Scheme 1B) was to obtain a peptide with a free thiol group for conjugation at the $N$-terminus of the chain (type II cyclic peptide). This 
required a precursor with two differently protected cysteines and a protected maleimide (Scheme 3). The cysteine that had to participate in cyclization was protected with the TFA-labile trityl group, and it was necessary to assess which thiol protecting group was suitable for the other cysteine. This group had to remain stable during the treatments required to obtain the cycle, that is, TFA treatment and maleimide deprotection.

a)

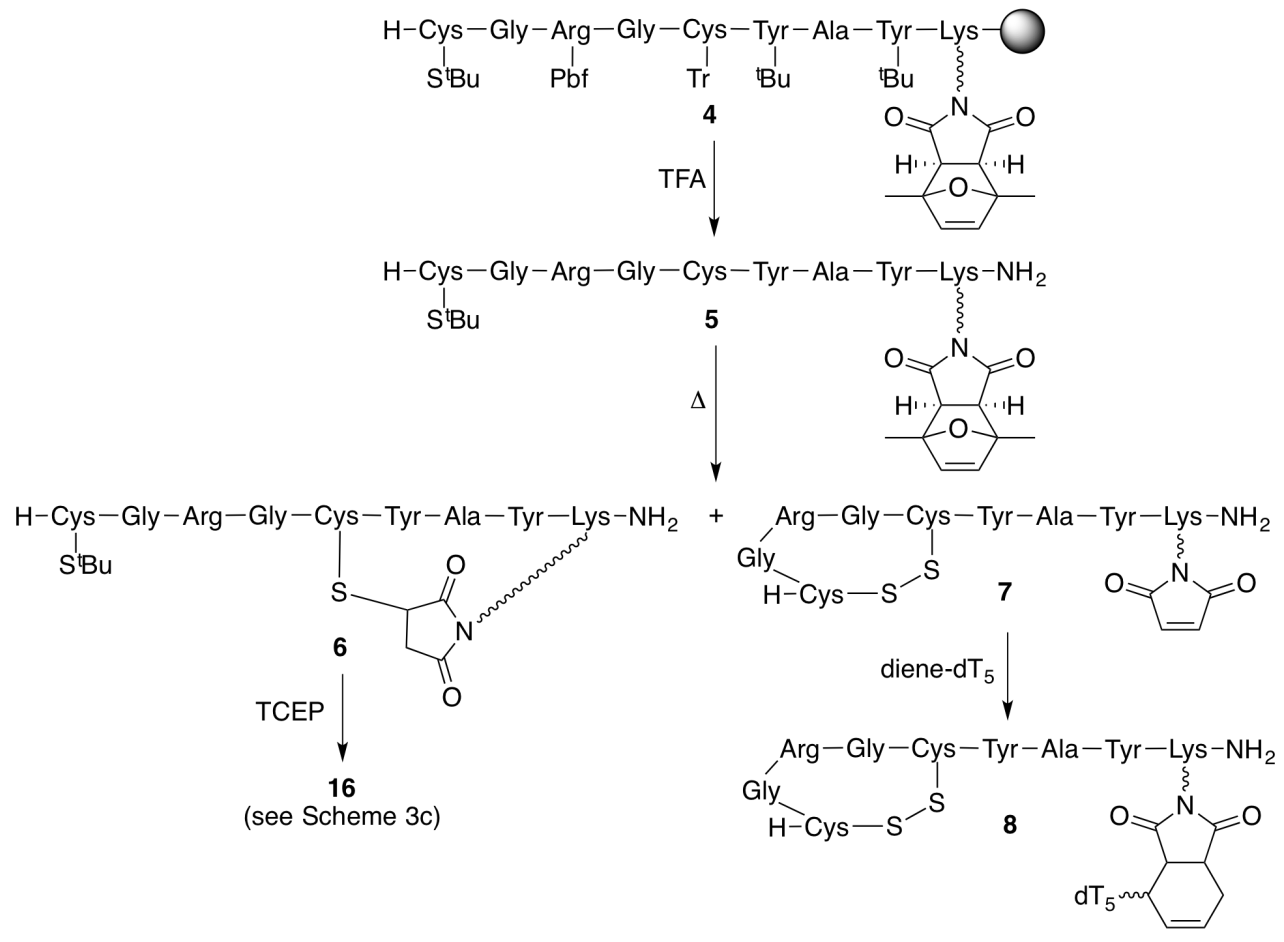
b) $\mathrm{H}$-Cys-Gly-Arg-Gly-Cys-Tyr-Ala-Tyr-Lys-O $\underset{\mathrm{TFA}}{\longrightarrow} \mathrm{H}-\mathrm{Cys}-\mathrm{Gly}-\mathrm{Arg}-\mathrm{Gly}-\mathrm{Cys}-\mathrm{Tyr}-\mathrm{Ala}-\mathrm{Tyr}-\mathrm{Lys}_{\mathrm{N}}-\mathrm{NH}_{2}$ (n) 10<smiles>O=CN1C=CCCN1</smiles>
9 H. 16
(see
Scheme 3c) 
c)

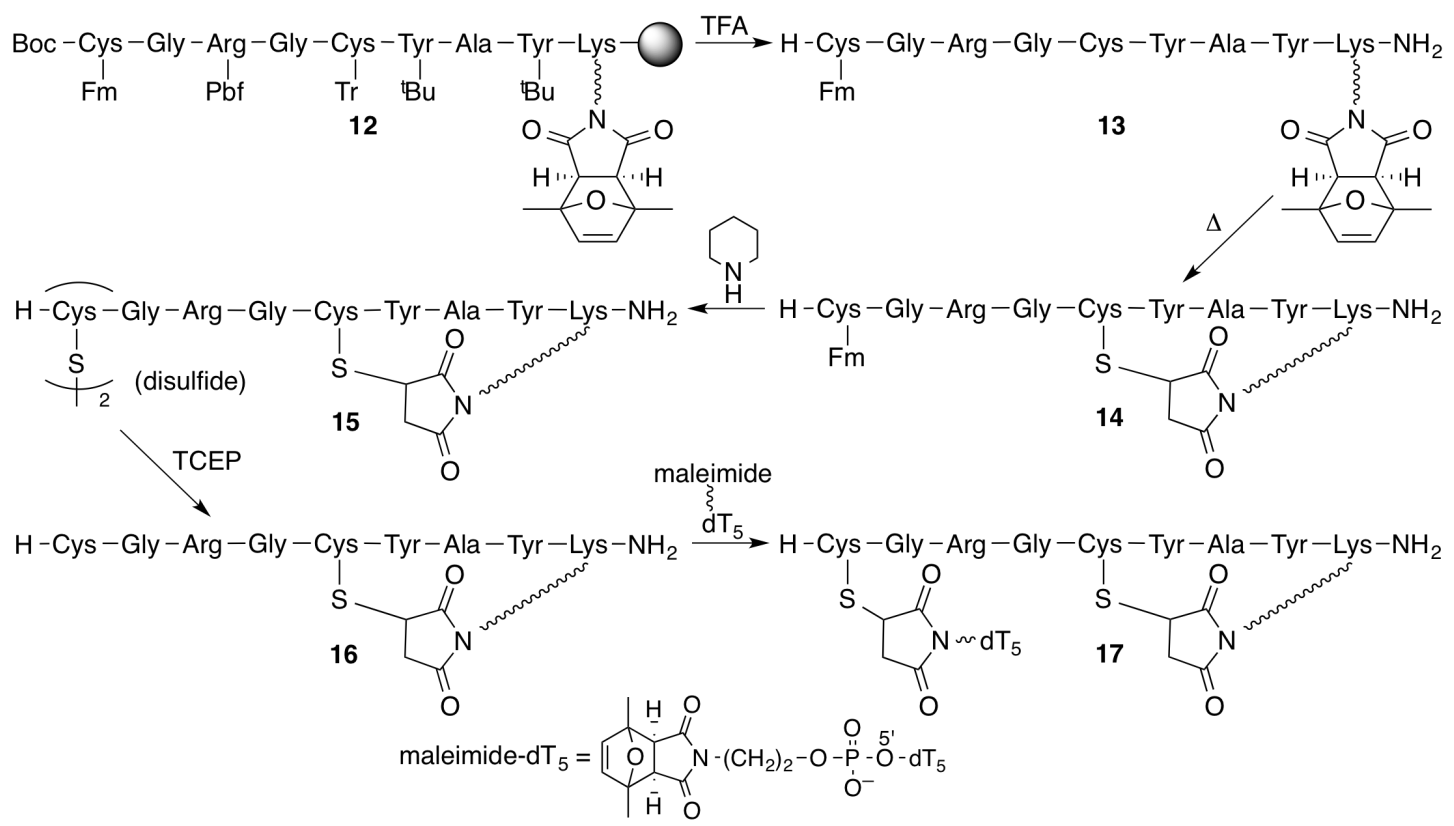

Scheme 3. Assays carried out to obtain cyclic peptide 16 (type II, alternative b in Scheme 1) using different thiol protecting groups for the $N$-terminal cysteine (the one to be involved in conjugation). a) Deprotection of the maleimide of peptide $\mathbf{5}$ afforded two products, $\mathbf{6}$ and $\mathbf{7}$, in similar ratio. The latter furnished conjugate 8 by reaction with diene- $\mathrm{dT}_{5}$. b) Removal of the Acm cysteine protecting group from 11 yielded complex mixtures of products in all the conditions tested. c) Cyclic peptide $\mathbf{1 6}$ was prepared by combining $\operatorname{Tr}$ and $\mathrm{Fm}$ as cysteine protecting groups, and conjugated with maleimido- $\mathrm{dT}_{5}$. Abbreviations: $\mathrm{Acm}=$ acetamidomethyl; Fm = 9-fluorenylmethyl.

We first evaluated the possibility of protecting the side chain of the $N$-terminal cysteine with the $\mathrm{S}^{\mathrm{t}} \mathrm{Bu}$ and acetamidomethyl groups, whose Fmoc derivatives are commercially available and which are TFA-stable (Schemes 3a and 3b). In preliminary experiments both Fmoc-Cys( $\left.\mathrm{S}^{t} \mathrm{Bu}\right)-\mathrm{OH}$ and Fmoc-Cys( $\left.\mathrm{Acm}\right)-\mathrm{OH}$ proved to be stable to maleimide deprotection conditions (heating in a microwave oven a solution of the compound in 1:1 $\mathrm{MeOH} / \mathrm{H}_{2} \mathrm{O}$ for 90 min at $90{ }^{\circ} \mathrm{C}$ ). Yet, when peptide 5 was submitted to these reaction conditions, two products were obtained (Scheme 3a): the target compound (6) with the thiosuccinimide-containing cycle, and a peptide (7) with a disulfide bridge and a free maleimide (the 6:7 ratio was 1:1 when the peptide was heated for $30 \mathrm{~min}$, and 3:2 when 
the reaction was extended to the 90 min typically required for full maleimide deprotection $^{27}$ ).

Mass spectrometric analysis confirmed presence of the $\mathrm{S}^{t} \mathrm{Bu}$ group in $\mathbf{6}$, its loss after reaction with tris(2-carboxyethyl)phosphine (TCEP) to yield 16 (see structure in Scheme 3c), and loss of the three $N$-terminal amino acids when 6 was digested with thrombin. Instead, the mass of 7 was lower than that of $\mathbf{6}$, and the product remained undigested upon treatment with thrombin. Final confirmation of the presence of a free maleimide in 7 was obtained from reaction with diene- $\mathrm{dT}_{5}$, which afforded the [disulfide cyclic peptide]-oligonucleotide conjugate 8. As expected, the Diels-Alder reaction is fully compatible with the presence of the disulfide. Even though the thiolmaleimide reaction slightly predominated over disulfide formation, the relative amounts of the products obtained after maleimide deprotection are too similar to consider this alternative a good synthetic method.

In the second group of assays (Scheme $3 b$ ) the $N$-terminal cysteine was protected with the acetamidomethyl $(\mathrm{Acm})$ group. Here the problem was that none of the conditions tested for its deprotection (reactions with either $\mathrm{Ag}^{+}$, iodine, or $\mathrm{Tl}^{3+}$ ) provided clean crudes with the target cyclic peptide (16) as the main product (see Supporting Information).

We next evaluated the combination of protecting groups shown for peptide-resin $\mathbf{1 2}$ (Scheme 3c), using commercially available $N$-Boc-Cys(Fm)-OH. In this case treatment with TFA deprotected the $N$-terminus and the other functional groups, except those on the $N$-terminal cysteine and the maleimide, to yield 13. Maleimide deprotection and the thiol-maleimide reaction that furnished the cycle (14) took place simultaneously, and, as described in the literature, ${ }^{28}$ treatment with piperidine removed the Fm protecting group and provided the disulfide (15). The cyclic peptide with the free thiol (16) was obtained 
after reduction with TCEP, and subsequent reaction with maleimido- $\mathrm{dT}_{5}$ afforded conjugate 17. Hence, the 9-fluorenylmethyl group is fully compatible with maleimide deprotection and peptide cyclization by the Michael-type thiol-ene reaction. Even though removal of the Fm group is accompanied by thiol to disulfide oxidation, which adds a reduction step, this group is suitable to mask the cysteine side chain provided that the so-protected cysteine is placed at the $N$-terminus. Peptide elongation using the Fmoc/ ${ }^{\mathrm{t}} \mathrm{Bu}$ approach rules out any other possibility.

\section{Synthesis and conjugation of type III cyclic polyamides (peptide and peptoid)}

Two different type III cyclic polyamides were synthesized (alternatives $\mathrm{c}$ and $\mathrm{d}$ in Scheme 1B). Here the functional group for conjugation appended from a residue placed within the cycle. In one case the polyamide was a peptide and the functional group for conjugation a thiol (20), while in the other it was a peptoid derivatized with an alkyne (24).

Scheme 4 depicts the preparation and conjugation of cyclic peptide $\mathbf{2 0}$. The $C$-terminal cysteine was protected with the trityl group, which reacted with the $N$-terminal, free maleimide upon treatment with TFA. Under these conditions the free thiol gave the Michael-type reaction and left untouched the internal, $\mathrm{S}^{\mathrm{t}} \mathrm{Bu}$-protected cysteine residue. In other words, the free thiol reacted much faster with the maleimide than with the $\mathrm{S}^{\mathrm{t}} \mathrm{Bu}$-protected cysteine. The side chain of the internal cysteine of the cyclic peptide (19) was deprotected by reaction with TCEP and, after purification, reacted with 5'maleimido-dT 5 to yield conjugate 21. 


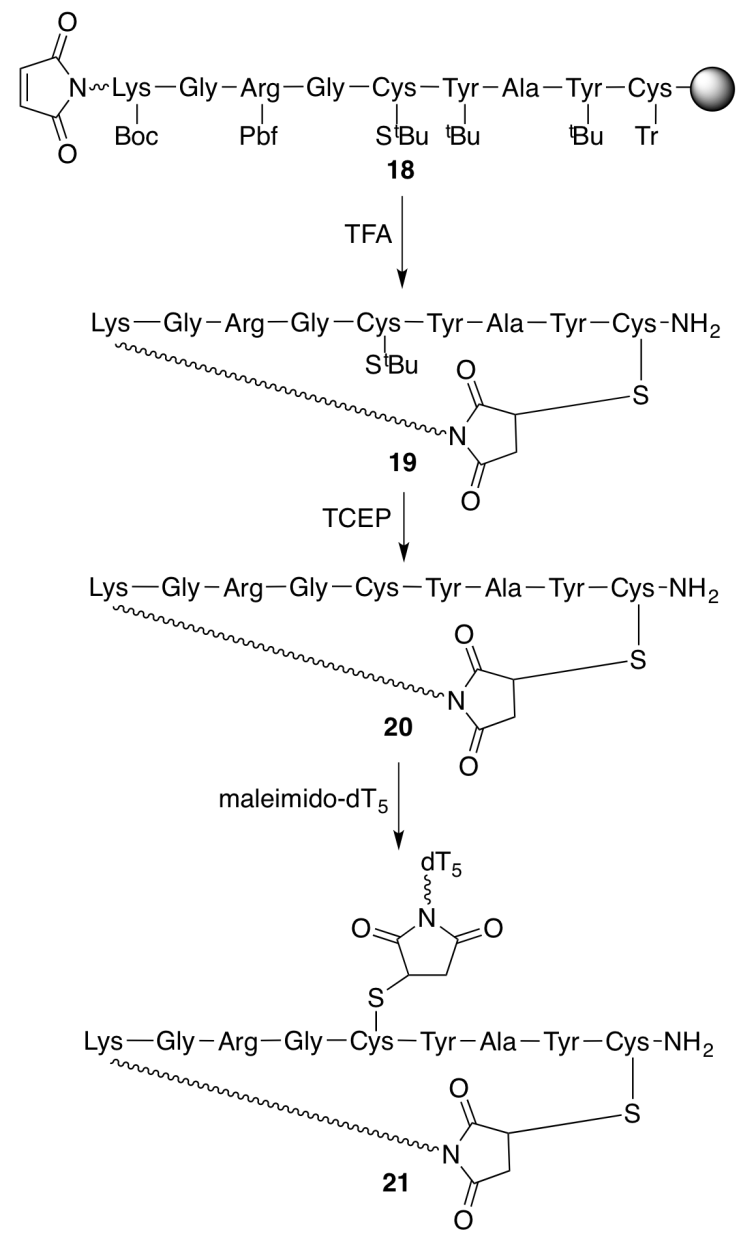

Scheme 4. Steps involved in the preparation of cyclic peptide 20 and conjugate 21.

Scheme 5 shows the preparation of a cyclic peptoid and the structure of the derived conjugate. On-resin assembly of the peptoid was carried out using the submonomer procedure, ${ }^{29}$ also on the Rink amide MBHA resin. As shown in the upper part of the scheme, chain elongation involves two subsequent steps, namely acylation with bromoacetic acid and reaction with an amine. Three of the amines required to synthesize peptoid $\mathbf{2 3}$ were commercially available (see list at the Supporting Information), and $S$-Tr-protected cysteamine and $N$-Boc-1,2-diaminoethane were prepared following described procedures. ${ }^{30,31}$ Cyclization with an $N$-terminal maleimide required incorporation of a maleimide-containing monomer, and 3-maleimidopropanoic acid is the cheapest alternative. However, since we had observed that the quality of 
cyclic peptide crudes was a bit lower when cyclization took place upon treatment with $\mathrm{TFA}^{22}$ we incorporated the 2,5-dimethylfuran-protected maleimidopropanoic acid. ${ }^{27}$ To introduce maleimide moieties at other positions of the chain, 2-[(2,5-dimethylfuranprotected) maleimide]-1-aminoethane ${ }^{23}$ should be employed. In the absence of two orthogonal maleimide protecting groups, this precludes use of maleimides for subsequent conjugation.

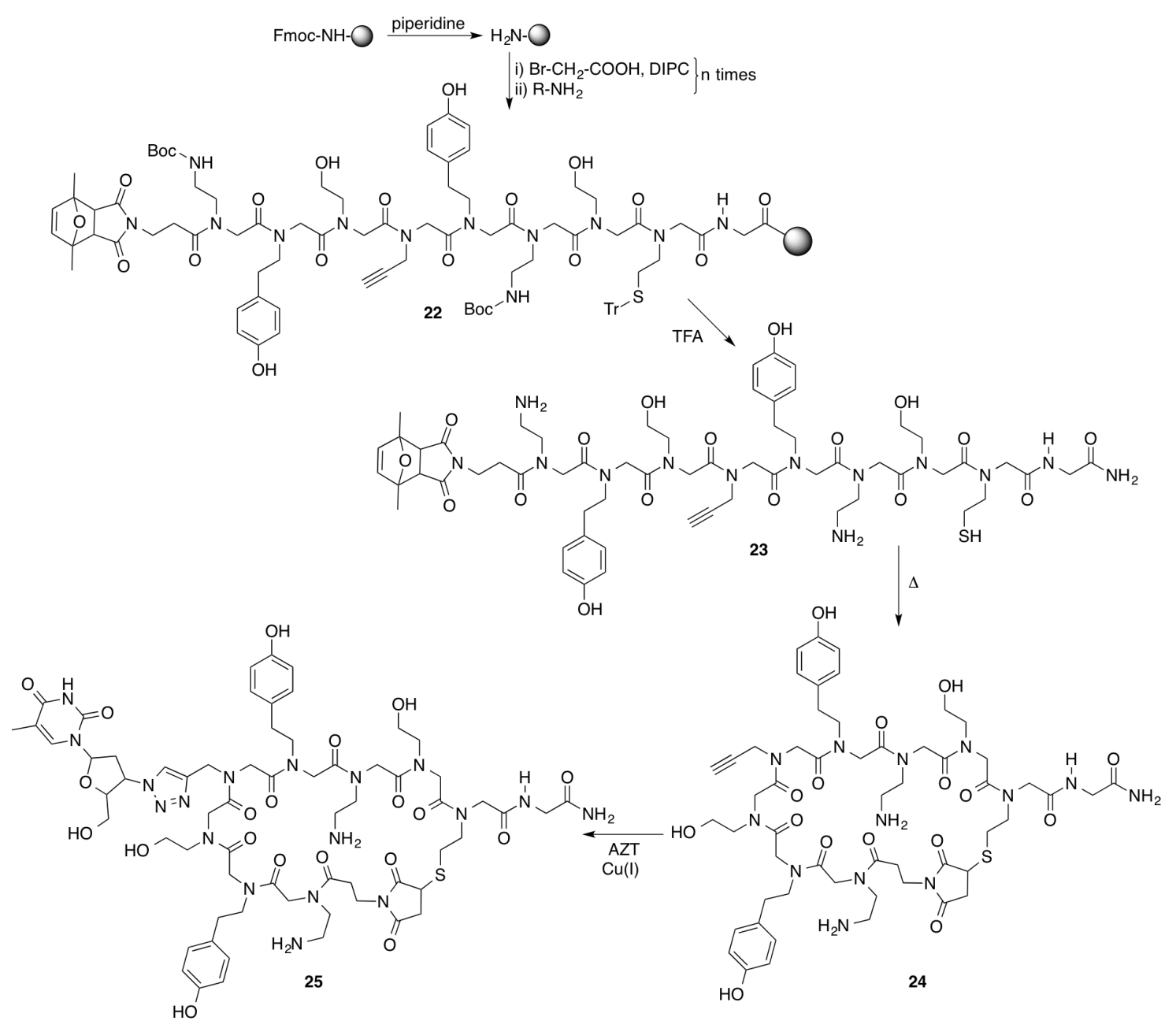

Scheme 5. Synthesis of cyclic peptoid 24 and conjugate 25 .

Chain assembly furnished the fully protected peptoid 22, from which all protecting groups except that on the maleimide were removed by treatment with TFA. Maleimide deprotection and cyclization took place simultaneously to afford 24. Finally, the $\mathrm{Cu}(\mathrm{I})$ - 
catalyzed Huisgen reaction between cyclic peptoid 24 and AZT (2',3'-dideoxy-3'azidothymidine) provided the target conjugate (25). The azide-containing molecule was in this case a simple nucleoside analog, but the high success of the $\mathrm{Cu}(\mathrm{I})$-catalyzed alkyne-azide cycloaddition has prompted many groups to develop methodology for the preparation of azide-derivatized oligonucleotides (see, for instance, references 32-34) circumventing the incompatibility between azides and phosphite-based reagents. ${ }^{35,36}$

\section{DISCUSSION}

We have shown that, by adequately combining differently protected cysteines, free and protected maleimides, and an alkyne, and choosing their relative position in the chain, it is possible to easily obtain cyclic peptides derivatized with a functional group allowing for subsequent conjugation, for instance with oligonucleotides.

In all cases cyclization was carried out using the thiol-ene Michael-type reaction. For this purpose, in all peptide precursors one of the cysteine residues was masked with the TFA-labile trityl group, so that the acidic treatment that follows chain elongation deprotected its thiol. When a free maleimide had been appended to the $N$-terminus of the chain, this unmasked thiol reacted with the maleimide to form the cycle (peptides 2 and 19) during the TFA deprotection step. ${ }^{22}$ Whenever a masked maleimide was incorporated into the chain, an additional deprotection step was required. Then, thermal removal of the maleimide protecting group (retro-Diels-Alder reaction) and cyclization took place simultaneously (peptide 14 and peptoid 24).

As required for conjugation with a suitably derivatized molecule, cyclic peptides had to incorporate an additional functional group. In this work, this group was either a maleimide, a thiol, or an alkyne. 
With the cyclization strategy that we have used, the only possibility to use a maleimide for conjugation is to assemble a peptide precursor with a free maleimide at the $\mathrm{N}$ terminus (to form the cycle) and a protected maleimide at any other position. Placing the lysine carrying the protected maleimide at the $C$-terminus (as in 1) furnishes type I cyclic peptides, with amino acids out of the cycle and the maleimide for conjugation at the $C$-terminal end. It is reasonable to surmise, on the basis of the results here described, that placing that lysine within the cycle will successfully provide cyclic peptides with an internal maleimide for conjugation. Maleimide-derivatized cyclic peptides (and any maleimide-containing compound) can be conjugated with diene-derivatized molecules, as in the synthesis of $\mathbf{3}$, where maleimide deprotection and conjugation took place simultaneously. It is also worth mentioning that, even though the proof of principle experiments here described were carried out with simple oligonucleotide sequences, the compatibility of oligonucleotides of different length and composition ${ }^{27}$ with the reaction conditions in which maleimides are deprotected suggests that any oligonucleotide can be linked to cyclic peptides. Alternatively, maleimide-derivatized cyclic peptides could be conjugated with thiols.

When the cyclic peptide is to be derivatized with a thiol for conjugation, the choice of protecting group for the cysteine providing this thiol depends on its position in the chain. If the goal is a type II cyclic peptide, the best alternative among those we have examined is to block the thiol with the Fm group, which is compatible with maleimide deprotection and cyclization and can be removed with no formation of byproducts. The only drawback is that removal of the Fm group by reaction with piperidine is accompanied by disulfide formation, an additional reduction step being thus necessary prior to conjugation. $N$-Terminal derivatization of a peptide with a thiol was here accomplished by introducing either suitably protected cysteine residue, but an $S$-blocked 
mercaptoacetic acid should also work. Use of cysteine derivatives has the advantage that the amino function can be further derivatized, allowing for the attachment a fluorophore, for instance, or any reporter group.

Conversely, the synthesis of cyclic peptides with the cysteine that provides the thiol for conjugation at any other position of the chain (not at the $N$-terminus) is much more straightforward (this is the case of type III peptide 20, but the same protection scheme could provide type I peptides). That cysteine can indeed be protected with the $\mathrm{S}^{\mathrm{t}} \mathrm{Bu}$ group, which remains stable during the acidic treatment that removes most of the protecting groups from the peptide and does not react with the free thiol resulting from the deprotection of Cys(Tr) (or if it does, the extent of the reaction is negligible). As stated before, at room temperature and under these strongly acidic conditions, formation of the cycle by reaction between the free thiol and the free maleimide is much quicker. Yet (see above and Scheme 3a), this is not the case when the peptide has to be heated. Thiol-derivatized cyclic peptides can be conjugated with maleimido-oligonucleotides, as in the case of $\mathbf{1 7}$ and $\mathbf{2 1 .}$

Type III cyclic peptoids derivatized for conjugation by the $\mathrm{Cu}(\mathrm{I})$-catalyzed Huisgen cycloaddition were also synthesized. In this case the key monomers were 3-(2,5dimethylfuran-protected)maleimidopropanoic $\quad$ acid, $^{27} \quad S$-trityl-cysteamine ${ }^{30}$ and propargylamine. Use of $S$-Fm-cysteamine instead of propargylamine would provide peptoids cyclized by the thiol-maleimide reaction and derivatized with a thiol group for conjugation.

As to the use of alkynes for conjugation, the triple bond can be installed at any position of the polyamide chain. It is neither affected by any of the peptide/peptoid synthesis reagents, nor by the thiol-maleimide cycle-forming reaction. We have prepared a [cyclic peptoid]-nucleoside conjugate to verify that synthesis proceeded as expected, and the 
triple bond was introduced in an internal position by reacting propargylamine with the haloacylated resin-linked, growing peptoid chain. Commercially available alkynecontaining L-amino acids or alkynoic acids allow triple bonds to be attached to peptides in a straightforward manner, which is also the case for derivatization with azides.

\section{CONCLUSIONS}

In summary, we have broadened the scope of applications of peptides cyclized making use of the maleimide-thiol reaction by introducing an additional group that allows for conjugation with oligonucleotides (or other molecules) utilizing click reactions, and shown that this methodology can also be employed with peptoids. The method here described is based on the adequate choice of protection for maleimides and thiols, as well as suitably placing maleimides, thiols or alkynes within the peptide/peptoid chain. These synthetic alternatives could also provide other cyclic polyamide scaffolds derivatized for conjugation, such as peptide nucleic acids.

It has been reported that subtle differences in the conjugation chemistry may have considerable impact on the biological outcome. ${ }^{37-39}$ Therefore, it is of interest to develop chemical tools giving access to differently linked conjugates. This manuscript describes methodology allowing oligonucleotides to be linked to cyclic peptides, either to an internal position, or to any of the two ends of a chain in which only some of the residues of the peptide are part of a chemically stable cycle. Both cyclic peptides and oligonucleotides (natural or modified) are relevant chemical goals that hold promise from the therapeutic and diagnostics point of view. So far there is lack of information as to the differential effect of linking oligonucleotides to cyclic peptides rather than the linear counterparts. Work on this subject is now in progress in the group, and results will be published in due time. 


\section{EXPERIMENTAL SECTION}

\section{General Methods.}

Peptide synthesis. All peptides were assembled on the Rink Amide resin, which was treated and washed with DCM $(3 \times)$, DMF $(3 \times), 20 \%$ piperidine/DMF $(2 \times 15 \mathrm{~min})$, $\operatorname{DCM}(3 \times), \operatorname{DMF}(3 \times)$ and $\mathrm{MeOH}(3 \times)$ prior to chain elongation. Incorporation of the first amino acid on the solid matrix and peptide elongation were carried out using 3 equiv. of Fmoc-amino acid, $\mathrm{HOBt} \cdot \mathrm{H}_{2} \mathrm{O}$ and $\mathrm{DIPC}$ (DIPC $=N, N^{\prime}-$ diisopropylcarbodiimide) dissolved in the minimum amount of DCM and a few drops of DMF (90 min), which was followed by washing with DCM, DMF and $\mathrm{MeOH}(3 \times)$. In case the coupling was not complete, as assessed by the Kaiser test, it was repeated using 2 equiv. of the reagents. Fmoc groups were removed by reaction with $20 \%$ piperidine/DMF $(1 \times 3 \mathrm{~min}+1 \times 10 \mathrm{~min})$, followed by washing (DMF, DCM). Activation of 3-maleimidopropanoic acid was carried out with DIPC (90 min reaction time). Even though activation with DIPC and $\mathrm{HOBt} \cdot \mathrm{H}_{2} \mathrm{O}$ seems not to cause any harm on the maleimide, use of only the carbodiimide is safer to prevent addition of HOBt to the maleimide of maleimidopropanoic acid)

Reaction with a TFA/ $\mathrm{H}_{2} \mathrm{O} / \mathrm{TIS}$ mixture at room temperature cleaved the peptide from the resin and removed most permanent protecting groups (see below and Schemes 2-4 for details). Filtrate and washings (DCM) were collected and concentrated under a $\mathrm{N}_{2}$ stream, and cold diethyl ether was added to the resulting oil. The mixture was centrifuged (10 $\left.\mathrm{min}, 5{ }^{\circ} \mathrm{C}, 4800 \mathrm{rpm}\right)$ and decanted. This procedure was repeated 3 times. Peptides were quantified by UV spectroscopy, from the absorbance of tyrosine residues at $280 \mathrm{~nm}\left(\varepsilon_{280} \mathrm{M}^{-1} \mathrm{~cm}^{-1}=1480\right)$. 
Peptoid synthesis. Peptoid 22 was also assembled on the Rink Amide resin, which was treated and washed as described above for peptide synthesis. For the acylation step, bromoacetic acid (25 equiv.) was dissolved in anh. DMF in a round-bottom flask, the solution was cooled to $0{ }^{\circ} \mathrm{C}$, and DIPC (25 equiv.) was added dropwise. After $5 \mathrm{~min}$, the solution was poured onto the resin in the syringe, and the mixture was stirred (shaker) under an Ar atmosphere for 45 min. The resin was filtered and washed (DCM, DMF, $\mathrm{iPrOH}$ and DCM, $3 \times$ each), and the amination step was carried out by reaction with the corresponding amine (20 equiv.) dissolved in anh. NMP $(500 \mu \mathrm{L})$ for $3 \mathrm{~h}$. After this reaction the resin was washed again $(\mathrm{DCM}, \mathrm{DMF}$ and $\mathrm{MeOH}, 3 \times$ each). Cleavage from the resin and removal of most permanent protecting groups was accomplished by reaction with TFA at room temperature (see details below, and Scheme 5), which was followed by washings with the cleavage mixture and DCM. Solvents and reagents were removed from the filtrate by means of a $\mathrm{N}_{2}$ stream until the solution became an oil. Cold diethyl ether (10 volumes) was added, and the mixture was centrifuged (10 min, 5 $\left.{ }^{\circ} \mathrm{C}, 4800 \mathrm{rpm}\right)$ and decanted. The ether addition plus centrifugation procedure was repeated 3 times. The crude was analyzed and purified by HPLC, quantified by UV spectroscopy (phenoxy group: $\left.\varepsilon_{270}\left(\mathrm{M}^{-1} \mathrm{~cm}^{-1}\right)=1450\right)$, and characterized by mass spectrometry.

HPLC. Unless otherwise stated, the following conditions were used:

- semipreparative HPLC, acidic conditions: Jupiter Proteo column; $3 \mathrm{~mL} / \mathrm{min}$; solvent A: $\mathrm{H}_{2} \mathrm{O}+0.1 \%$ TFA; solvent B: ACN $+0.1 \%$ TFA

- analytical HPLC, acidic conditions: Phenomenex C18, $4 \mu \mathrm{m}$, Jupiter Proteo column; 1 $\mathrm{mL} / \mathrm{min}$; solvent $\mathrm{A}: \mathrm{H}_{2} \mathrm{O}+0.045 \%$ TFA); solvent $\mathrm{B}: \mathrm{ACN}+0.36 \% \mathrm{TFA}$ 
- analytical HPLC (also used for purification at a small scale), buffered medium: Kromasil C18, $10 \mu \mathrm{m}$ column; $1 \mathrm{~mL} / \mathrm{min}$; solvent A: $0.05 \mathrm{M}$ TEAA (triethylammonium acetate) in water; solvent $\mathrm{B}: 1: 1 \mathrm{H}_{2} \mathrm{O} / \mathrm{ACN}$.

MW-Promoted polyamide deprotection and cyclization. The [protected maleimido]containing polyamide was dissolved in a $1: 1$ (v/v) $\mathrm{MeOH}: \mathrm{H}_{2} \mathrm{O}$ mixture at a concentration between 25 and $100 \mu \mathrm{M}$ in a microwave flask. The flask was sealed and heated in the microwave oven (Biotage InitiatorTM Classic) at $90{ }^{\circ} \mathrm{C}$ for $90 \mathrm{~min}$ (with stirring and internal probe for temperature monitoring). Methanol was then removed under reduced pressure and the resulting aqueous solution was analyzed by HPLC. Alternatively, methanol removal was followed by lyophilization, and the crude was redissolved in water for HPLC analysis.

Assessment of cyclization: Reaction with $\mathrm{H}_{2} \mathrm{O}_{2}$. Formation of a cyclic product was confirmed by reacting the peptide, either linear or cyclic, with a dilute solution of $\mathrm{H}_{2} \mathrm{O}_{2}$ (3.5\%) for $1 \mathrm{~h}$, and subsequent MS analysis. ${ }^{23}$ When the peptide is linear, $\mathrm{H}_{2} \mathrm{O}_{2}$ oxidizes the free thiol to sulfonic acid (and the mass increases 48 units), whereas when the peptide is cyclic the thioether is oxidized to sulfoxide (and the mass increases 16 units). This method cannot be used when the peptide to be analyzed incorporates a $\mathrm{Cys}\left(\mathrm{S}^{\mathrm{t}} \mathrm{Bu}\right)$ residue, because this disulfide is oxidized to different products. ESI Mass spectrometric analysis showed formation of mixtures of products with and without loss of the $\mathrm{S}^{t} \mathrm{Bu}$ group. When analysis was performed in the negative mode, the main group of peaks corresponded to loss of the $S^{t} B u$ group and oxidation of the thiol to sulfonic acid $(+3$ oxygen atoms, $\mathrm{M}+48)$.

Assessment of cyclization: Digestion with thrombin. Reaction with thrombin can also be used to assess circularity. Thrombin cleaves the Arg-Gly bond in linear GRG peptide sequences, but not when this sequence is within a cycle. $20 \mu \mathrm{g}$ of peptide and $5 \mathrm{u}$ of 
thrombin, dissolved in a 1:2 PBS: $\mathrm{H}_{2} \mathrm{O}$ solution (PBS buffer: $140 \mathrm{mM} \mathrm{NaCl}, 2.7 \mathrm{mM}$ $\mathrm{KCl}, 10 \mathrm{mM} \mathrm{Na} 2 \mathrm{HPO}_{4}$ and $1.8 \mathrm{mM} \mathrm{KH}_{2} \mathrm{PO}_{4}, \mathrm{pH}=7.23$ ), were incubated at room temperature overnight. The crude was readily analyzed by MALDI-TOF MS.

Deprotection of $C y s\left(S^{t} B u\right)$ and reduction of disulfide bridges. TCEP (500 equiv) was added to a $0.3 \mathrm{mM}$ solution of the polyamide in $\mathrm{H}_{2} \mathrm{O}(1-3 \mathrm{~mL})$. The $\mathrm{pH}$ was adjusted to 5 with an aqueous dilute $\mathrm{NaOH}$ solution, and the mixture was stirred at room temperature for $3 \mathrm{~h}$. Water was removed by lyophilization and the crude analyzed by HPLC.

Diels-Alder cycloadditions. The maleimido- or protected maleimido-containing peptide and diene- $\mathrm{dT}_{5}$ were dissolved in water, and the amounts required to carry out the reaction (typical reagent ratio was 1:1) were taken from each of these solutions and mixed. This mixture was diluted with water (or water and methanol, to end up with a 1:1 proportion, if MW-promoted maleimide deprotection and conjugation were to take place simultaneously) to reach a reagent concentration between 30 and $300 \mu \mathrm{M}$. The maleimide+diene mixture was reacted overnight at $37^{\circ} \mathrm{C}$. The [protected maleimide]+diene mixture was reacted in a $\mathrm{MW}$ oven for $90 \mathrm{~min}$ at $90{ }^{\circ} \mathrm{C}$. Solvents were removed by evaporation under reduced pressure and/or lyophilization, and reaction crudes were analyzed by HPLC. Conjugates were purified by HPLC and characterized by MALDI-TOF MS.

Michael-type reactions. Aliquots of aqueous solutions containing the required amounts of maleimido-containing compound and the corresponding thiol derivative were mixed (final concentration of polyamide: $50-150 \mathrm{mM}$ ). The mixture was stirred at room temperature under an Ar atmosphere overnight. After lyophilization, reaction crudes were analyzed by HPLC. Conjugates were purified by HPLC and characterized by MALDI-TOF MS. 
Assays to assess the stability of cysteine derivatives to microwave-promoted maleimidedeprotection conditions. The stabilities of Fmoc-Cys $\left(\mathrm{S}^{t} \mathrm{Bu}\right)-\mathrm{OH}$, Fmoc-Cys(Acm)-OH and Boc-Cys(Fm)-OH were assessed by dissolving some 5-10 $\mathrm{mg}$ of the product in $\mathrm{MeOH}: \mathrm{H}_{2} \mathrm{O} 1: 1(\mathrm{v} / \mathrm{v})$, and heating the resulting solution at $90{ }^{\circ} \mathrm{C}$ for $90 \mathrm{~min}$ in the microwave oven. Solvent was removed under reduced pressure and the crude was analyzed ${ }^{1} \mathrm{H}$ NMR. In all cases a spectrum with the same set of signals as for the commercial compound was obtained, with one exception: partial loss of the tBu signal in the case of Boc-Cys(Fm)-OH, due to partial loss of the Boc group upon heating.

Cyclic maleimido*-Lys-Gly-Arg-Gly-Cys*-Tyr-Ala-Tyr-Lys(Prot.Mal.)-NH2, 2 (the label $*$ refers to the units linked in the cycle). Peptide 2 was assembled on $110 \mathrm{mg}$ of resin $(\mathrm{f}=0.65 \mathrm{mmol} / \mathrm{g})$. Treatment of peptide-resin 1 with TFA/TIS/ $\mathrm{H}_{2} \mathrm{O}$ 90:5:5 (TIS = triisopropylsilane), $2 \times 1 \mathrm{~h}$, followed by purification at the semipreparative scale (linear gradient from 15 to $35 \%$ of $B$ in $30 \mathrm{~min}, t_{R}=15.1 \mathrm{~min}$ ), afforded 2 as a white solid $(12.1 \mu \mathrm{mol}, 17 \%)$. Analytical HPLC: acidic conditions, linear gradient from 10 to $50 \%$ of $\mathrm{B}$ in $30 \mathrm{~min}, \mathrm{t}_{\mathrm{R}}=16.2 \mathrm{~min}$. MALDI-TOF MS (DHB, positive mode): $\mathrm{m} / z 1347.4$ $[\mathrm{M}-\text { furan }+\mathrm{H}]^{+}, 1369.4$ [M-furan+Na] $]^{+}$M calcd for $\mathrm{C}_{66} \mathrm{H}_{91} \mathrm{~N}_{17} \mathrm{O}_{18} \mathrm{~S} 1441.6 ; \mathrm{M}$-furan calcd for $\mathrm{C}_{60} \mathrm{H}_{83} \mathrm{~N}_{17} \mathrm{O}_{17} \mathrm{~S}$ 1345.6. MALDI-TOF MS after reaction with $\mathrm{H}_{2} \mathrm{O}_{2}$ (DHB, positive mode): $m / z 1362.8[\mathrm{M} \text {-furan }+16+\mathrm{H}]^{+}$; M-furan+16 calcd for $\mathrm{C}_{60} \mathrm{H}_{83} \mathrm{~N}_{17} \mathrm{O}_{18} \mathrm{~S}$ 1361.6. MALDI-TOF MS after digestion with thrombin (DHB, positive mode): $\mathrm{m} / \mathrm{z}$ $1347.3[\mathrm{M}+\mathrm{H}]^{+} 1369.3[\mathrm{M}+\mathrm{Na}]^{+}, 1385.2[\mathrm{M}+\mathrm{K}]^{+} ; \mathrm{M}$ calcd for $\mathrm{C}_{66} \mathrm{H}_{91} \mathrm{~N}_{17} \mathrm{O}_{18} \mathrm{~S}$ 1441.6, M-furan calcd for $\mathrm{C}_{60} \mathrm{H}_{83} \mathrm{~N}_{17} \mathrm{O}_{17} \mathrm{~S}$ 1345.6. No digestion was observed.

Conjugate 3, [cyclic maleimido*-Lys-Gly-Arg-Gly-Cys*-Tyr-Ala-Tyr-Lys(Mal.)-

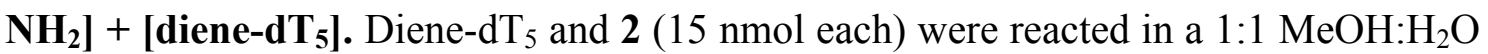


solution $(500 \mu \mathrm{L}, 30 \mu \mathrm{M})$ in a MW oven for 90 min at $90{ }^{\circ} \mathrm{C}$. HPLC Analysis of the crude showed that the extent of the cycloaddition was 90\%. Analytical HPLC: buffered medium, gradient from $5 \%$ to $60 \%$ of $\mathrm{B}$ in $30 \mathrm{~min}, \mathrm{t}_{\mathrm{R}}=22.3 \mathrm{~min}$. MALDI-TOF (THAP, negative mode): $m / z 2962.7[\mathrm{M}-\mathrm{H}]$; $\mathrm{M}$ calcd for $\mathrm{C}_{116} \mathrm{H}_{158} \mathrm{~N}_{27} \mathrm{O}_{53} \mathrm{P}_{5} \mathrm{~S}$ 2963.9.

H-Cys(S ${ }^{t}$ Bu)-Gly-Arg-Gly-Cys-Tyr-Ala-Tyr-Lys(Prot.Mal.)-NH ${ }_{2}, \quad$ 5. $\quad$ Fmoc$\mathrm{Cys}\left(\mathrm{S}^{t} \mathrm{Bu}\right)-\mathrm{OH}$ was incorporated onto $121 \mu \mathrm{mol}$ of Fmoc-Gly-Arg(Pbf)-Gly-Cys(Tr)$\operatorname{Tyr}\left({ }^{\mathrm{t}} \mathrm{Bu}\right)-\mathrm{Ala}-\mathrm{Tyr}\left({ }^{\mathrm{t}} \mathrm{Bu}\right)-\mathrm{Lys}($ Prot.Mal.)-resin, and the Fmoc group removed to yield 4. 4 Was deprotected and cleaved by reaction with TFA/TIS/ $\mathrm{H}_{2} \mathrm{O}$ 95:2.5:2.5, $2 \times 1 \mathrm{~h}$, and purified at the semipreparative scale (linear gradient from 25 to $50 \%$ of $\mathrm{B}$ in $30 \mathrm{~min}, \mathrm{t}_{\mathrm{R}}$ $=9.6 \mathrm{~min}) . \mathrm{A}$ white solid corresponding to the desired peptide (5) was obtained (28 $\mu \mathrm{mol}, 23 \%$ ). Analytical HPLC: acidic conditions, linear gradient from 5 to $50 \%$ of B in $30 \mathrm{~min}, \mathrm{t}_{\mathrm{R}}=22.7 \mathrm{~min}$. MALDI-TOF MS (DHB, positive mode): $\mathrm{m} / \mathrm{z} 1258.9$ $[\mathrm{M} \text {-furan }+\mathrm{H}]^{+}$; $\mathrm{M}$ calcd for $\mathrm{C}_{60} \mathrm{H}_{87} \mathrm{~N}_{15} \mathrm{O}_{15} \mathrm{~S}_{3}$ 1353.6, M-furan calcd for $\mathrm{C}_{54} \mathrm{H}_{79} \mathrm{~N}_{15} \mathrm{O}_{14} \mathrm{~S}_{3}$ 1257.5. MALDI-TOF MS after reaction with $\mathrm{H}_{2} \mathrm{O}_{2}$ (DHB, negative mode): $m / z 1216.6$ $\left[\mathrm{M}-\text { furan-S }{ }^{t} \mathrm{Bu}+48-\mathrm{H}\right]^{-}, \quad 1264.5 \quad\left[\mathrm{M}-\text { furan-S }{ }^{t} \mathrm{Bu}+48+48-\mathrm{H}\right]^{-} ; \quad \mathrm{M}+48$ calcd for $\mathrm{C}_{60} \mathrm{H}_{87} \mathrm{~N}_{15} \mathrm{O}_{18} \mathrm{~S}_{3}$ 1401.6, M-furan-S ${ }^{\mathrm{t}} \mathrm{Bu}+48$ calcd for $\mathrm{C}_{50} \mathrm{H}_{71} \mathrm{~N}_{15} \mathrm{O}_{17} \mathrm{~S}_{2}$ 1217.5. MALDITOF MS after digestion with thrombin (DHB, positive mode): $\mathrm{m} / \mathrm{z} \quad 876.4$ $\left[\mathrm{M}-\right.$ furan-[Cys $\left.\left.\left(\mathrm{S}^{t} \mathrm{Bu}\right)-\mathrm{Gly}-\mathrm{Arg}\right]+\mathrm{Na}\right]^{+}, 892.4\left[\mathrm{M}-\right.$ furan-[Cys $\left.\left.\left(\mathrm{S}^{\mathrm{t}} \mathrm{Bu}\right)-\mathrm{Gly}-\mathrm{Arg}\right]+\mathrm{K}\right]^{+} ; \mathrm{M}$ calcd for $\mathrm{C}_{45} \mathrm{H}_{59} \mathrm{~N}_{9} \mathrm{O}_{12} \mathrm{~S} 949.4, \mathrm{M}$-furan calcd for $\mathrm{C}_{39} \mathrm{H}_{51} \mathrm{~N}_{9} \mathrm{O}_{11} \mathrm{~S}$ 853.3.

Deprotection of the maleimide of 5.5 (100 nmol) was dissolved in $\mathrm{H}_{2} \mathrm{O} / \mathrm{MeOH}(4$ $\mathrm{mL}$ ) to yield a $25 \mu \mathrm{M}$ solution, which was heated in a MW oven as described above (General Methods). Two different products, namely 6 and 7, were obtained (no trace of 5 was detected in any case), in a ratio that varied depending on the reaction time: the 6:7 
ratio was 49:51 after 30 min heating, 56:44 after $60 \mathrm{~min}$, and 59:41 after 90 min. 6 And 7 were separated using analytical acidic HPLC conditions, and characterized by MALDI-TOF MS before and after reaction with thrombin (see below). For an additional proof of structure, samples of $\mathbf{6}$ and $\mathbf{7}$ were subsequently reacted as described below to yield compounds $\mathbf{1 6}$ and $\mathbf{8}$, respectively, which were also characterized by MS.

Cyclic H-Cys(S ${ }^{t}$ Bu)-Gly-Arg-Gly-Cys*-Tyr-Ala-Tyr-Lys*-NH ${ }_{2}, \quad 6$. Analytical HPLC: acidic conditions, linear gradient from 5 to $50 \%$ of $\mathrm{B}$ in $30 \mathrm{~min}, \mathrm{t}_{\mathrm{R}}=20.1 \mathrm{~min}$. MALDI-TOF MS (DHB, positive mode): $m / z$ 1258.9 [M+H] $]^{+}, 1280.9[\mathrm{M}+\mathrm{Na}]^{+}, 1296.8$ $[\mathrm{M}+\mathrm{K}]^{+} ; \mathrm{M}$ calcd for $\mathrm{C}_{54} \mathrm{H}_{79} \mathrm{~N}_{15} \mathrm{O}_{14} \mathrm{~S}_{3}$ 1257.5. MALDI-TOF MS after reaction with

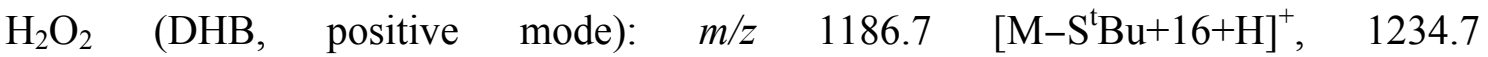
$\left[\mathrm{M}-\mathrm{S}^{\mathrm{t}} \mathrm{Bu}+16+48+\mathrm{H}\right]^{+}, 1290.7[\mathrm{M}+32+\mathrm{H}]^{+} ; \mathrm{M}+32$ calcd for $\mathrm{C}_{54} \mathrm{H}_{79} \mathrm{~N}_{15} \mathrm{O}_{16} \mathrm{~S}_{3}$ 1289.5, $\mathrm{M}-\mathrm{S}^{t} \mathrm{Bu}+16$ calcd for $\mathrm{C}_{50} \mathrm{H}_{71} \mathrm{~N}_{15} \mathrm{O}_{15} \mathrm{~S}_{2}$ 1185.5. MALDI-TOF MS after reaction with thrombin (DHB, positive mode): $m / z$ 876.4 [M-[Cys( ( $\left.\left.\left.^{t} \mathrm{Bu}\right)-\mathrm{Gly}-\mathrm{Arg}\right]+\mathrm{Na}\right]^{+}, 892.4$ $\left[\mathrm{M}-\left[\mathrm{Cys}\left(\mathrm{S}^{\mathrm{t}} \mathrm{Bu}\right)-\mathrm{Gly}-\mathrm{Arg}\right]+\mathrm{K}\right]^{+} ; \mathrm{M}-\left[\mathrm{Cys}\left(\mathrm{S}^{\mathrm{t}} \mathrm{Bu}\right)-\mathrm{Gly}-\mathrm{Arg}\right]$ calcd for $\mathrm{C}_{39} \mathrm{H}_{51} \mathrm{~N}_{9} \mathrm{O}_{11} \mathrm{~S}$ 853.3.

Cyclic H-Cys-Gly-Arg-Gly-Cys*-Tyr-Ala-Tyr-Lys*-NH2, 16. Compound 6 (67 nmol) was reacted with TCEP according to the general procedures. Compound $\mathbf{1 6}$ was obtained in $76 \%$ yield (based on the HPLC trace). Analytical HPLC: acidic conditions, linear gradient from 5 to $50 \%$ of $\mathrm{B}$ in $30 \mathrm{~min}, \mathrm{t}_{\mathrm{R}}=16.1 \mathrm{~min}$. MALDI-TOF MS (DHB, positive mode): $m / z 1170.7[\mathrm{M}+\mathrm{H}]^{+}, 1192.7[\mathrm{M}+\mathrm{Na}]^{+}, 1208.7[\mathrm{M}+\mathrm{K}]^{+}$; M calcd for $\mathrm{C}_{50} \mathrm{H}_{71} \mathrm{~N}_{15} \mathrm{O}_{14} \mathrm{~S}_{2}$ 1169.5. MALDI-TOF MS after reaction with $\mathrm{H}_{2} \mathrm{O}_{2}$ (DHB, negative mode): $m / z 1232.6[\mathrm{M}+48+16-\mathrm{H}]^{-} ; \mathrm{M}+48+16$ calcd for $\mathrm{C}_{50} \mathrm{H}_{71} \mathrm{~N}_{15} \mathrm{O}_{18} \mathrm{~S}_{2}$ 1233.5. MALDI-TOF MS after digestion with thrombin (DHB, positive mode): $\mathrm{m} / \mathrm{z} 876.5$ 
$\left[\mathrm{M}-[\text { Cys-Gly-Arg]+Na }]^{+}, 892.5 \text { [M-[Cys-Gly-Arg]+K] }\right]^{+}$; M-[Cys-Gly-Arg] calcd for $\mathrm{C}_{39} \mathrm{H}_{51} \mathrm{~N}_{9} \mathrm{O}_{11} \mathrm{~S} 853.4$.

Cyclic H-Cys*-Gly-Arg-Gly-Cys*-Tyr-Ala-Tyr-Lys(Prot.Mal.)-NH2, 7. Analytical HPLC: acidic conditions, linear gradient from 5 to $50 \%$ of $\mathrm{B}$ in $30 \mathrm{~min}, \mathrm{t}_{\mathrm{R}}=16.7 \mathrm{~min}$. MALDI-TOF MS (DHB, positive mode): $m / z$ 1168.8 [M+H] $]^{+}, 1190.7[\mathrm{M}+\mathrm{Na}]^{+}, 1206.7$ $[\mathrm{M}+\mathrm{K}]^{+}$; $\mathrm{M}$ calcd for $\mathrm{C}_{50} \mathrm{H}_{69} \mathrm{~N}_{15} \mathrm{O}_{14} \mathrm{~S}_{2}$ 1167.5. MALDI-TOF MS after reaction with $\mathrm{H}_{2} \mathrm{O}_{2}$ (DHB, negative mode): $m / z$ 1264.7 [M+48+48-H]-, $\mathrm{M}+48+48$ calcd for $\mathrm{C}_{50} \mathrm{H}_{71} \mathrm{~N}_{15} \mathrm{O}_{20} \mathrm{~S}_{2}$ 1265.4. MALDI-TOF MS after digestion with thrombin (DHB, positive mode): $m / z \quad 1168.8[\mathrm{M}+\mathrm{H}]^{+}, \quad 1190.7 \quad[\mathrm{M}+\mathrm{Na}]^{+}, 1206.7 \quad[\mathrm{M}+\mathrm{K}]^{+} ; \quad \mathrm{M}$ calcd for $\mathrm{C}_{50} \mathrm{H}_{69} \mathrm{~N}_{15} \mathrm{O}_{14} \mathrm{~S}_{2}$ 1167.5. No digestion was detected.

Conjugate 8, [cyclic H-Cys*-Gly-Arg-Gly-Cys*-Tyr-Ala-Tyr-Lys(Mal.)-NH ${ }_{2}$ + [diene-dT 5 ]. $7(15 \mathrm{nmol})$ and diene-dT $\mathrm{T}_{5}(25 \mathrm{nmol})$ were dissolved in water $(65 \mu \mathrm{L})$, and allowed to react overnight at room temperature, yielding the desired product $\mathbf{8}$ (8.8 nmol, 59\% conjugation and purification yield). 8 Was purified using acidic analytical HPLC conditions. Analytical HPLC: buffered medium, linear gradient from 5 to $60 \%$ of $\mathrm{B}$ in $30 \mathrm{~min}, \mathrm{t}_{\mathrm{R}}=23.0 \mathrm{~min}$. MALDI-TOF MS (THAP, negative mode): $\mathrm{m} / z 2785.0$ $[\mathrm{M}-\mathrm{H}]^{-}, 2822.9[\mathrm{M}-2 \mathrm{H}+\mathrm{K}]^{-}$; $\mathrm{M}$ calcd for $\mathrm{C}_{106} \mathrm{H}_{144} \mathrm{~N}_{25} \mathrm{O}_{50} \mathrm{P}_{5} \mathrm{~S}_{2} 2785.8$.

H-Cys(Acm)-Gly-Arg-Gly-Cys-Tyr-Ala-Tyr-Lys(Prot.Mal.)-NH $\mathbf{N}_{2}, \quad 10 . \quad$ FmocCys(Acm)-OH was incorporated onto $34 \mu \mathrm{mol}$ of peptide-resin Fmoc-Gly-Arg(Pbf)Gly-Cys-Tyr $\left({ }^{\mathrm{t} B u}\right)-\mathrm{Ala}-\operatorname{Tyr}\left({ }^{\mathrm{t}} \mathrm{Bu}\right)-\mathrm{Lys}(\operatorname{Prot}$ Mal.)-resin, and the Fmoc group removed to yield 9. Treatment with TFA/TIS $/ \mathrm{H}_{2} \mathrm{O}$ 95:2.5:2.5, $2 \times 1 \mathrm{~h}$, and purification at the semipreparative scale (linear gradient from 25 to $70 \%$ of $\mathrm{B}$ in $30 \mathrm{~min}, \mathrm{t}_{\mathrm{R}}=6.2 \mathrm{~min}$ ) 
afforded a white solid corresponding to the desired peptide 10 (11.4 $\mu \mathrm{mol}, 34 \%)$. Analytical HPLC: acidic conditions, linear gradient from 5 to $50 \%$ of $\mathrm{B}$ in $30 \mathrm{~min}, \mathrm{t}_{\mathrm{R}}=$ 19.0 min. MALDI-TOF MS (DHB, positive mode): $m / z 1170.7$ [M-furan-Acm $+\mathrm{H}]^{+}$ 1241.8 [M-furan $+\mathrm{H}]^{+}$; $\mathrm{M}$ calcd for $\mathrm{C}_{59} \mathrm{H}_{84} \mathrm{~N}_{16} \mathrm{O}_{16} \mathrm{~S}_{2}$ 1336.6, M-furan calcd for $\mathrm{C}_{53} \mathrm{H}_{76} \mathrm{~N}_{16} \mathrm{O}_{15} \mathrm{~S}_{2}$ 1240.5. MALDI-TOF MS after reaction with $\mathrm{H}_{2} \mathrm{O}_{2}$ (DHB, negative mode): $\quad m / z \quad 1169.0 \quad[\mathrm{M}-\text { furan-Acm-H] }]^{-}, \quad 1217.0 \quad\left[\mathrm{M}-\right.$ furan-Acm+48-H] ${ }^{-}, \quad 1233.0$ $[\mathrm{M}-\text { furan-Acm+48+16-H] }]^{-} ; \quad \mathrm{M}+48$ calcd for $\mathrm{C}_{59} \mathrm{H}_{84} \mathrm{~N}_{16} \mathrm{O}_{19} \mathrm{~S}_{2} \quad$ 1384.5, $\mathrm{M}-$ furan-Acm +48 calcd for $\mathrm{C}_{50} \mathrm{H}_{71} \mathrm{~N}_{15} \mathrm{O}_{17} \mathrm{~S}_{2}$ 1217.5.

Cyclic H-Cys(Acm)-Gly-Arg-Gly-Cys*-Tyr-Ala-Tyr-Lys*-NH2, 11. Compound 10 (100 nmol) was dissolved in the $\mathrm{H}_{2} \mathrm{O} / \mathrm{MeOH}$ mixture $(1 \mathrm{~mL}, 100 \mu \mathrm{M})$ and heated in a MW oven according to the general procedures, yielding the desired product 11 (30 nmol, 30\% cyclization and purification yield). 11 Was purified using acidic analytical HPLC conditions. Analytical HPLC: acidic conditions, linear gradient from 5 to $50 \%$ of $\mathrm{B}$ in $30 \mathrm{~min}, \mathrm{t}_{\mathrm{R}}=16.0,16.2 \mathrm{~min}$ (2 diastereomers). MALDI-TOF MS (DHB, positive mode): $m / z \quad 1241.7 \quad[\mathrm{M}+\mathrm{H}]^{+}, \quad 1263.7 \quad[\mathrm{M}+\mathrm{Na}]^{+}, 1279.7 \quad[\mathrm{M}+\mathrm{K}]^{+} ; \quad \mathrm{M}$ calcd for $\mathrm{C}_{53} \mathrm{H}_{76} \mathrm{~N}_{16} \mathrm{O}_{15} \mathrm{~S}_{2}$ 1240.5. MALDI-TOF MS after reaction with $\mathrm{H}_{2} \mathrm{O}_{2}$ (DHB, positive mode): $m / z$ 1203.2 $[\mathrm{M}-\mathrm{Acm}+32+\mathrm{H}]^{+} ; \mathrm{M}+32$ calcd for $\mathrm{C}_{53} \mathrm{H}_{76} \mathrm{~N}_{16} \mathrm{O}_{17} \mathrm{~S}_{2}$ 1272.5, $\mathrm{M}-\mathrm{Acm}+32$ calcd for $\mathrm{C}_{50} \mathrm{H}_{71} \mathrm{~N}_{15} \mathrm{O}_{16} \mathrm{~S}_{2}$ 1201.6.

\section{Assays to remove the Acm group from peptide 11.}

Reaction with AgOTf. Compound 11 (30 nmol) was dissolved in TFA (1 mL), and $\operatorname{AgOTf}(1 \mathrm{mg}, 3.9 \mu \mathrm{mol})$ and anisole $(430 \mu \mathrm{L}, 3.9 \mu \mathrm{mol})$ were added. The mixture was allowed to react for $1 \mathrm{~h}$, after which time solvent was removed under reduced pressure and the crude redissolved with DTT $(1 \mathrm{mg}, 6.5 \mu \mathrm{mol})$ in a 1:1 mixture of $\mathrm{H}_{2} \mathrm{O}: \mathrm{AcOH}$ 
$(1.5 \mathrm{~mL})$. After $30 \mathrm{~min}$, the solution was frozen and lyophilized. The crude was then redissolved in water and analyzed, yielding a very complex HPLC profile. Integration of the HPLC trace and MALDI-TOF MS analysis showed that the desired product was obtained in less than $5 \%$ yield.

Reaction with $\mathrm{I}_{2}$. Compound $11(500 \mathrm{nmol})$ was dissolved in a 9:1 $\mathrm{H}_{2} \mathrm{O}$ :AcOH mixture $(100 \mu \mathrm{L})$ and $\mathrm{I}_{2}(100 \mu \mathrm{L}$ of a $50 \mathrm{mM}$ solution in $\mathrm{MeOH})$ was added. The mixture was allowed to react for $4 \mathrm{~h}$. The reaction was quenched with $0.2 \mathrm{M}$ sodium ascorbate (20 $\mu \mathrm{L}$ ), and methanol was removed under reduced pressure. Neither HPLC analysis nor MALDI-TOF MS of the crude showed the presence of the desired product, but one resulting from the addition of $1-4$ iodines to the peptide.

Reaction with $\mathrm{Tl}(\mathrm{OAc})_{3}$. Compound $11(50 \mathrm{nmol})$ was dissolved in TFA (500 $\left.\mu \mathrm{L}\right)$, and a solution of $\mathrm{Tl}(\mathrm{OAc})_{3}(390 \mu \mathrm{g}, 100 \mathrm{nmol})$ and anisole $(10.9 \mu \mathrm{L}, 100 \mathrm{nmol})$ in TFA $(10$ $\mu \mathrm{L}$ ) was added. The mixture was reacted for $1 \mathrm{~h}$ at $0{ }^{\circ} \mathrm{C}$, and the solvent was removed with a $\mathrm{N}_{2}$ stream. $10 \%$ Acetic acid in water $(1 \mathrm{~mL})$ and chloroform $(1 \mathrm{~mL})$ were added, and the two fractions were collected separately. HPLC and MALDI-TOF analysis of the two fractions showed the presence of multiple products, none of which could be identified.

H-Cys(Fm)-Gly-Arg-Gly-Cys-Tyr-Ala-Tyr-Lys(Prot.Mal.)-NH2, 13. Boc-Cys(Fm)OH was incorporated onto $31 \mu \mathrm{mol}$ of Fmoc-Gly-Arg(Pbf)-Gly-Cys(Tr)-Tyr( $\left.{ }^{\mathrm{t}} \mathrm{Bu}\right)$-Ala$\operatorname{Tyr}\left({ }^{\mathrm{t}} \mathrm{Bu}\right)-\mathrm{Lys}\left(\right.$ Prot.Mal.)-resin. Treatment with TFA/TIS/ $\mathrm{H}_{2} \mathrm{O}$ 95:2.5:2.5, $2 \times 1 \mathrm{~h}$, and purification at the semipreparative scale (linear gradient from 30 to $60 \%$ of B in $30 \mathrm{~min}$, $\left.t_{R}=9.5 \mathrm{~min}\right)$ afforded a white solid corresponding to the desired peptide $\mathbf{1 3}(9.6 \mu \mathrm{mol}$, 31\%). Analytical HPLC: acidic conditions, linear gradient from 30 to $60 \%$ of B in 30 $\min , t_{R}=7.0 \min$. MALDI-TOF (DHB, positive mode): $m / z 1348.9[\mathrm{M}-\text { furan }+\mathrm{H}]^{+}$, 
$1370.8[\mathrm{M}-\text { furan }+\mathrm{Na}]^{+}, 1386.8[\mathrm{M} \text {-furan }+\mathrm{K}]^{+} ; \mathrm{M}$ calcd for $\mathrm{C}_{70} \mathrm{H}_{89} \mathrm{~N}_{15} \mathrm{O}_{15} \mathrm{~S}_{2}$ 1443.6, M-furan calcd for $\mathrm{C}_{64} \mathrm{H}_{81} \mathrm{~N}_{15} \mathrm{O}_{14} \mathrm{~S}_{2}$ 1347.6. MALDI-TOF MS after reaction with $\mathrm{H}_{2} \mathrm{O}_{2}$ (DHB, negative mode): $\quad m / z \quad 1214.4 \quad[\mathrm{M}-\text { furan-Fm+48-H }]^{-} \quad 1232.6$ $\left[\mathrm{M}-\right.$ furan-Fm+48+16-H]; $\quad \mathrm{M}+48+16$ calcd for $\mathrm{C}_{70} \mathrm{H}_{89} \mathrm{~N}_{15} \mathrm{O}_{19} \mathrm{~S}_{2} \quad$ 1507.6, M-furan-Fm+48+16 calcd for $\mathrm{C}_{50} \mathrm{H}_{71} \mathrm{~N}_{15} \mathrm{O}_{18} \mathrm{~S}_{2} 1233.5$.

Cyclic H-Cys(Fm)-Gly-Arg-Gly-Cys*-Tyr-Ala-Tyr-Lys*-NH2, 14. 13 (400 nmol) was dissolved in the $\mathrm{H}_{2} \mathrm{O} / \mathrm{MeOH}$ mixture $(4 \mathrm{~mL}, 100 \mu \mathrm{M})$, heated in a $\mathrm{MW}$ oven according to the general procedures, and purified using analytical HPLC conditions to yield 14 (184 nmol, 46\% cyclization and purification yield). Analytical HPLC: acidic conditions, linear gradient from 30 to $60 \%$ of $\mathrm{B}$ in $30 \mathrm{~min}, \mathrm{t}_{\mathrm{R}}=4.8 \mathrm{~min}$. MALDI-TOF MS (DHB, positive mode): $m / z 1348.8[\mathrm{M}+\mathrm{H}]^{+}, 1370.8[\mathrm{M}+\mathrm{Na}]^{+}, 1386.7[\mathrm{M}+\mathrm{K}]^{+} ; \mathrm{M}$ calcd for $\mathrm{C}_{64} \mathrm{H}_{81} \mathrm{~N}_{15} \mathrm{O}_{14} \mathrm{~S}_{2}$ 1347.6. MALDI-TOF after reaction with $\mathrm{H}_{2} \mathrm{O}_{2}$ (DHB, positive mode): $m / z 1202.7[\mathrm{M}-\mathrm{Fm}+32+\mathrm{H}]^{+}, 1380.9[\mathrm{M}+32+\mathrm{H}]^{+} ; \mathrm{M}+32$ calcd for $\mathrm{C}_{64} \mathrm{H}_{81} \mathrm{~N}_{15} \mathrm{O}_{16} \mathrm{~S}_{2} 1379.5$.

\section{Disulfide dimer of cyclic H-Cys-Gly-Arg-Gly-Cys*-Tyr-Ala-Tyr-Lys*-NH2, 15.14}

(92 nmol) was dissolved in 33\% piperidine in DCM $(500 \mu \mathrm{L})$, and the mixture reacted for $45 \mathrm{~min}$. The solvent was then removed under reduced pressure, and coevaporations with acetonitrile. The crude was purified using analytical HPLC acidic conditions (linear gradient from 5 to $50 \%$ of $\mathrm{B}$ in $30 \mathrm{~min}, \mathrm{t}_{\mathrm{R}}=17.8 \mathrm{~min}$ ), yielding 15 (41.6 nmol, $45 \%$ reaction and purification yield). MALDI-TOF MS (DHB, positive mode): $\mathrm{m} / \mathrm{z}$ $1170.6[\text { monomer }+\mathrm{H}]^{+}, 2338.3[\mathrm{M}+\mathrm{H}]^{+}$; $\mathrm{M}$ calcd for $\mathrm{C}_{100} \mathrm{H}_{114} \mathrm{~N}_{30} \mathrm{O}_{28} \mathrm{~S}_{4} 2336.9$. 

nmol) was reacted with TCEP as described above. Compound $\mathbf{1 6}$ was obtained in $89 \%$ yield (based on the HPLC trace) and purified using analytical HPLC conditions. Analytical HPLC: acidic conditions, linear gradient from 5 to $50 \%$ of $\mathrm{B}$ in $30 \mathrm{~min}, \mathrm{t}_{\mathrm{R}}=$ 15.8 min. MALDI-TOF MS (DHB, positive mode): $\mathrm{m} / \mathrm{z} 1171.1[\mathrm{M}+\mathrm{H}]^{+}, 1193.0$ $[\mathrm{M}+\mathrm{Na}]^{+} ; \mathrm{M}$ calcd for $\mathrm{C}_{50} \mathrm{H}_{71} \mathrm{~N}_{15} \mathrm{O}_{14} \mathrm{~S}_{2}$ 1169.5.

\section{Conjugate 17, [cyclic H-Cys-Gly-Arg-Gly-Cys*-Tyr-Ala-Tyr-Lys*-NH ${ }_{2}$ ] +} [maleimido-dT 5 ]. [Protected maleimido]-dT 5 (25 nmol) was dissolved in the 1:1 $\mathrm{MeOH}: \mathrm{H}_{2} \mathrm{O}$ solution $(1 \mathrm{~mL}, 25 \mu \mathrm{M})$, and heated in the microwave oven for $60 \mathrm{~min}$ at $90{ }^{\circ} \mathrm{C}$. Methanol was removed under reduced pressure. HPLC Analysis of the crude (buffered medium) showed that maleimide deprotection had taken place at an $85 \%$ extent. This crude was used immediately for the conjugation reaction. Analytical HPLC: buffered medium, linear gradient from 5 to $60 \%$ of $\mathrm{B}$ in $30 \mathrm{~min}, \mathrm{t}_{\mathrm{R}}=18.3 \mathrm{~min}$. MALDITOF MS (THAP, negative mode): $m / z$ 1661.7 [M-H] ${ }^{-}$M calcd for $\mathrm{C}_{56} \mathrm{H}_{72} \mathrm{~N}_{11} \mathrm{O}_{38} \mathrm{P}_{5}$ 1661.3

Mal-dT $_{5}(5 \mathrm{nmol})$ was mixed with $16(4 \mathrm{nmol})$ dissolved in water $(375 \mu \mathrm{L})$ and reacted overnight. The desired product (17) was obtained in $73 \%$ yield (based on the HPLC trace). Analytical HPLC: buffered medium, linear gradient from 5 to $60 \%$ of $\mathrm{B}$ in 30 $\min , t_{\mathrm{R}}=22.0 \mathrm{~min}$. MALDI-TOF MS (THAP, negative mode): $m / z 2830.2[\mathrm{M}-\mathrm{H}]^{-} ; \mathrm{M}$ calcd for $\mathrm{C}_{106} \mathrm{H}_{143} \mathrm{~N}_{26} \mathrm{O}_{52} \mathrm{P}_{5} \mathrm{~S}_{2} 2830.8$.

Cyclic Lys*-Gly-Arg-Gly-Cys(S ${ }^{t}$ Bu)-Tyr-Ala-Tyr-Cys*-NH2, 19. The synthesis of 18 was carried out on $110 \mathrm{mg}$ of resin ( $\mathrm{f}=0.65 \mathrm{mmol} / \mathrm{g}$ ). After reaction with TFA/TIS $/ \mathrm{H}_{2} \mathrm{O} 90: 5: 5,2 \times 1 \mathrm{~h}$, and purification at the semipreparative scale (linear 
gradient from 25 to $50 \%$ of $\mathrm{B}$ in $30 \mathrm{~min}, \mathrm{t}_{\mathrm{R}}=9.8 \mathrm{~min}$ ), 19 was obtained as a white solid (8.7 $\mu \mathrm{mol}, 11 \%)$. Analytical HPLC: acidic conditions, linear gradient from 20 to $60 \%$ of $\mathrm{B}$ in $30 \mathrm{~min}, \mathrm{t}_{\mathrm{R}}=11.7 \mathrm{~min}$. MALDI-TOF MS (DHB, positive mode): $\mathrm{m} / \mathrm{z} 1259.1$ $[\mathrm{M}+\mathrm{H}]^{+}$; $\mathrm{M}$ calcd for $\mathrm{C}_{54} \mathrm{H}_{79} \mathrm{~N}_{15} \mathrm{O}_{14} \mathrm{~S}_{3}$ 1257.5. MALDI-TOF MS after reaction with $\mathrm{H}_{2} \mathrm{O}_{2}$ (DHB, positive mode): $m / z$ 1186.6 [M-S $\left.{ }^{t} \mathrm{Bu}+16+\mathrm{H}\right]^{+}, 1306.7[\mathrm{M}+32+16+\mathrm{H}]^{+}$; $\mathrm{M}-\mathrm{S}^{\mathrm{t}} \mathrm{Bu}+16$ calcd for $\mathrm{C}_{50} \mathrm{H}_{71} \mathrm{~N}_{15} \mathrm{O}_{15} \mathrm{~S}_{2}$ 1185.5; $\mathrm{M}+32+16$ calcd for $\mathrm{C}_{54} \mathrm{H}_{79} \mathrm{~N}_{15} \mathrm{O}_{17} \mathrm{~S}_{3}$ 1305.5. MALDI-TOF MS after digestion with thrombin (DHB, positive mode): $\mathrm{m} / \mathrm{z}$ 1259.2[M+H] $]^{+}, 1281.2[\mathrm{M}+\mathrm{Na}]^{+}, 1297.2[\mathrm{M}+\mathrm{K}]^{+}$; $\mathrm{M}$ calcd for $\mathrm{C}_{54} \mathrm{H}_{79} \mathrm{~N}_{15} \mathrm{O}_{14} \mathrm{~S}_{3}$ 1257.5. No digestion was observed.

Cyclic Lys*-Gly-Arg-Gly-Cys-Tyr-Ala-Tyr-Cys*-NH2, 20. Compound 19 (100 nmol) was reacted with as described above (General Methods). Compound 20 was obtained in $80 \%$ yield (based on the HPLC trace) and purified using acidic analytical HPLC conditions. Analytical HPLC: acidic conditions, linear gradient from 10 to $50 \%$ of $\mathrm{B}$ in $30 \mathrm{~min} . \mathrm{t}_{\mathrm{R}}=13.5 \mathrm{~min}$. MALDI-TOF MS (DHB, positive mode): $\mathrm{m} / z 1170.9$ $[\mathrm{M}+\mathrm{H}]^{+} ; \mathrm{M}$ calcd for $\mathrm{C}_{50} \mathrm{H}_{71} \mathrm{~N}_{15} \mathrm{O}_{14} \mathrm{~S}_{2}$ 1169.5.

\section{Conjugate 21, [cyclic Lys*-Gly-Arg-Gly-Cys-Tyr-Ala-Tyr-Cys*-NH ${ }_{2}$ +} [maleimido-dT 5 ]. $20(10 \mathrm{nmol})$ and [Protected maleimido]-dT5 $(10 \mathrm{nmol})$ were dissolved in a 3:1 MeOH: $\mathrm{H}_{2} \mathrm{O}$ solution $(500 \mu \mathrm{L}, 20 \mu \mathrm{M})$, and heated in a MW oven for 90 min at $90{ }^{\circ} \mathrm{C}$. Methanol was removed under reduced pressure. The desired product (21) was obtained in 77\% yield (based on the HPLC trace). Analytical HPLC: buffered medium, linear gradient from 5 to $50 \%$ of $\mathrm{B}$ in $30 \mathrm{~min}, \mathrm{t}_{\mathrm{R}}=14.9 \mathrm{~min}$. MALDI-TOF MS (THAP, negative mode): $m / z 2829.5[\mathrm{M}-\mathrm{H}]^{-} ; \mathrm{M}$ calcd for $\mathrm{C}_{106} \mathrm{H}_{143} \mathrm{~N}_{26} \mathrm{O}_{52} \mathrm{P}_{5} \mathrm{~S}_{2} 2830.7$. 
[Protected

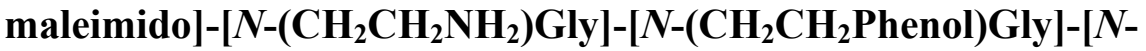

$\left.\left(\mathrm{CH}_{2} \mathrm{CH}_{2} \mathrm{OH}\right) \mathrm{Gly}\right]-\left[N-\left(\right.\right.$ Propargyl)Gly]-[ $N-\left(\mathrm{CH}_{2} \mathrm{CH}_{2}\right.$ Phenol)Gly]-[ $N-$

$\left.\left(\mathrm{CH}_{2} \mathrm{CH}_{2} \mathrm{NH}_{2}\right) \mathrm{Gly}\right]-\left[\mathrm{N}-\left(\mathrm{CH}_{2} \mathrm{CH}_{2} \mathrm{OH}\right) \mathrm{Gly}\right]-\left[\mathrm{N}-\left(\mathrm{CH}_{2} \mathrm{CH}_{2} \mathrm{SH}\right) \mathrm{Gly}\right]-\mathrm{Gly}-\mathrm{NH}_{2}$,

23.

Peptoid 23 was assembled on $100 \mathrm{mg}$ of resin $(f=0.72 \mathrm{mmol} / \mathrm{g}$ ). Treatment of the peptoid-resin 22 with $\mathrm{TFA} / m$-cresol/TIS/ $\mathrm{H}_{2} \mathrm{O}$ 90:5:2.5:2.5, $2 \times 1 \mathrm{~h}$, followed by purification at the semipreparative scale (linear gradient from 20 to $40 \%$ of B in $30 \mathrm{~min}$, $\left.\mathrm{t}_{\mathrm{R}}=12.0 \mathrm{~min}\right)$, afforded 23 as a white solid $(3.0 \mu \mathrm{mol}, 4.1 \%)$. Analytical HPLC: acidic conditions, linear gradient from 20 to $40 \%$ of $\mathrm{B}$ in $30 \mathrm{~min}, \mathrm{t}_{\mathrm{R}}=9.7 \mathrm{~min}$. MALDI-TOF MS (THAP/CA, positive mode): $m / z$ 1194.7 [M-furan+H] $]^{+}, 1290.8[\mathrm{M}+\mathrm{H}]^{+} ; \mathrm{M}$ calcd for $\mathrm{C}_{60} \mathrm{H}_{83} \mathrm{~N}_{13} \mathrm{O}_{17} \mathrm{~S}$ 1289.6, M-furan calcd for $\mathrm{C}_{54} \mathrm{H}_{75} \mathrm{~N}_{13} \mathrm{O}_{16} \mathrm{~S}$ 1193.5. MALDI-TOF MS after reaction with $\mathrm{H}_{2} \mathrm{O}_{2}$ (THAP/CA, negative mode): $m / z$ 1240.7 [M-furan+48-H]'; $\mathrm{M}$-furan +48 calcd for $\mathrm{C}_{54} \mathrm{H}_{75} \mathrm{~N}_{13} \mathrm{O}_{19} \mathrm{~S} 1241.5$.

Cyclic maleimido*-[N-( $\left.\left.\mathrm{CH}_{2} \mathrm{CH}_{2} \mathrm{NH}_{2}\right) \mathrm{Gly}\right]-\left[N-\left(\mathrm{CH}_{2} \mathrm{CH}_{2}\right.\right.$ Phenol $\left.) \mathrm{Gly}\right]-[N-$

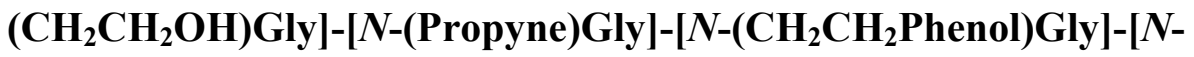
$\left.\left(\mathrm{CH}_{2} \mathrm{CH}_{2} \mathrm{NH}_{2}\right) \mathrm{Gly}\right]-\left[N-\left(\mathrm{CH}_{2} \mathrm{CH}_{2} \mathrm{OH}\right) \mathrm{Gly}\right]-\left[N-\left(\mathrm{CH}_{2} \mathrm{CH}_{2} \mathrm{SH}\right) \mathrm{Gly}\right]$ *-Gly-NH $2 \quad 24.23$ (100 nmol) was dissolved in the $\mathrm{H}_{2} \mathrm{O} / \mathrm{MeOH}$ solution $(1 \mathrm{~mL}, 100 \mu \mathrm{M})$ and heated in a MW oven according to the general procedures. $\mathrm{MeOH}$ was removed under reduced pressure. The desired product (24) was obtained in 79\% yield (based on the HPLC trace). Analytical HPLC: acidic conditions, linear gradient from 20 to $40 \%$ of B in 30 $\min , \mathrm{t}_{\mathrm{R}}=15.8 \mathrm{~min} . \mathrm{MALDI}-\mathrm{TOF}$ MS (THAP/CA, positive mode): $m / z 1194.7[\mathrm{M}+\mathrm{H}]^{+}$; $\mathrm{M}$ calcd for $\mathrm{C}_{54} \mathrm{H}_{75} \mathrm{~N}_{13} \mathrm{O}_{16} \mathrm{~S}$ 1193.5. MALDI-TOF MS after reaction with $\mathrm{H}_{2} \mathrm{O}_{2}$ (THAP/CA, positive mode): $m / z 1210.7[\mathrm{M}+16+\mathrm{H}]^{+}$; $\mathrm{M}+16$ calcd for $\mathrm{C}_{54} \mathrm{H}_{75} \mathrm{~N}_{13} \mathrm{O}_{17} \mathrm{~S}$ 1209.5 
Conjugate 25, [cyclic maleimido*-[N-( $\left.\left.\mathrm{CH}_{2} \mathrm{CH}_{2} \mathrm{NH}_{2}\right) \mathrm{Gly}\right]-\left[\mathrm{N}-\left(\mathrm{CH}_{2} \mathrm{CH}_{2}\right.\right.$ Phenol)Gly]$\left[N-\left(\mathrm{CH}_{2} \mathrm{CH}_{2} \mathrm{OH}\right) \mathrm{Gly}\right]-[N-($ Propyne $) G l y]-\left[N-\left(\mathrm{CH}_{2} \mathrm{CH}_{2}\right.\right.$ Phenol $\left.) \mathrm{Gly}\right]-[N-$ $\left.\left.\left(\mathrm{CH}_{2} \mathrm{CH}_{2} \mathrm{NH}_{2}\right) \mathrm{Gly}\right]-\left[\mathrm{N}-\left(\mathrm{CH}_{2} \mathrm{CH}_{2} \mathrm{OH}\right) \mathrm{Gly}\right]-\left[\mathrm{N}-\left(\mathrm{CH}_{2} \mathrm{CH}_{2} \mathrm{SH}\right) \mathrm{Gly}\right]^{*}-\mathrm{Gly}-\mathrm{NH}_{2}\right]+\mathrm{AZT}$. A $0.5 \mathrm{mM}$ solution of $\mathrm{CuSO}_{4}$ in water $(50 \mu \mathrm{L}, 25 \mathrm{nmol})$ and a $12 \mathrm{mM}$ solution of sodium ascorbate in water $(50 \mu \mathrm{L}, 600 \mathrm{nmol})$ were mixed in a microwave flask under an Ar atmosphere, and stirred during 5 minutes. Then TBTA (tris[(1-benzyl-1H-1,2,3triazol-4-yl)methyl]amine) (50 $\mu \mathrm{L}$ of a $0.5 \mathrm{mM}$ solution in $\left.\mathrm{MeOH}: \mathrm{H}_{2} \mathrm{O} 3: 2,24 \mathrm{nmol}\right)$, AZT (3'-azido-3'-deoxythymidine) $(110 \mu \mathrm{L}$ of a $2 \mathrm{mM}$ aqueous solution, $200 \mathrm{nmol})$ and compound $24(100 \mu \mathrm{L}$ of a $290 \mu \mathrm{M}$ aqueous solution, $29 \mathrm{nmol})$ were added. The mixture was heated in a microwave oven for $1 \mathrm{~h}$ at $90{ }^{\circ} \mathrm{C} . \mathrm{MeOH}$ was then removed under reduced pressure. The desired product (25) was obtained in 90\% yield (based on the HPLC trace, calculated from compound 24). Analytical HPLC: acidic conditions, linear gradient from 5 to $50 \%$ of $\mathrm{B}$ in $30 \mathrm{~min}, \mathrm{t}_{\mathrm{R}}=17.1 \mathrm{~min}$. MALDI-TOF MS (DHB, positive mode): $m / z: 1462.4[\mathrm{M}+\mathrm{H}]^{+} ; 1484.3[\mathrm{M}+\mathrm{Na}]^{+} ; \mathrm{M}$ calcd for $\mathrm{C}_{64} \mathrm{H}_{88} \mathrm{~N}_{18} \mathrm{O}_{20} \mathrm{~S}$ 1460.6 .

$\boldsymbol{S}$-Trityl cysteamine hydrochloride. Trityl chloride (279 $\mathrm{mg}, 1.6 \mathrm{mmol})$ and cysteamine hydrochloride (200 mg, $1.8 \mathrm{mmol})$ were dissolved in DMF (1.5 mL) and stirred overnight at room temperature. The reaction was then quenched with cold water $(10 \mathrm{~mL})$, and the precipitated formed was filtered and washed with cold water $(3 \times 5$ $\mathrm{mL}$ ). A white solid (480 mg, 85\% yield) was obtained. Rf (Hexanes/AcOEt/TEA $75: 20: 5)=0.68 ;{ }^{1} \mathrm{H}$ NMR $\left(\mathrm{CD}_{3} \mathrm{OD}, 400 \mathrm{MHz}\right): \delta 7.5-7.1(\mathrm{~m}, 15 \mathrm{H}$, aromatics $) ; 2.58(\mathrm{t}$, $\left.J=6.9,2 \mathrm{H}, \underline{\mathrm{CH}_{2}}-\mathrm{NH}_{2}\right) ; 2.47$ (t, $\left.J=6.8,2 \mathrm{H}, \mathrm{S}-\underline{\mathrm{CH}}_{2}\right) \mathrm{ppm} ;{ }^{13} \mathrm{C} \mathrm{NMR}\left(\mathrm{CD}_{3} \mathrm{OD}\right.$, 100MHz): $\delta 145.6,130.7,129.2,128.2,68.4,39.7,30.1$; ESI MS (positive mode): $\mathrm{m} / \mathrm{z}$ $319.9[\mathrm{M}+\mathrm{H}]^{+}, 639.0[2 \mathrm{M}+\mathrm{H}]^{+} ; \mathrm{M}$ calcd for $\mathrm{C}_{21} \mathrm{H}_{21} \mathrm{NS} 319.14$. 
$N$-Boc-ethylenediamine. A solution of Boc anhydride (1.2 g, $5.5 \mathrm{mmol})$ in DCM (80 $\mathrm{mL})$ was added dropwise during 15 minutes to a solution of ethylenediamine $(2.2 \mathrm{~mL}$, $33.5 \mathrm{mmol})$ in DCM $(10 \mathrm{~mL})$. The mixture was stirred for $1 \mathrm{~h}$ at $0{ }^{\circ} \mathrm{C}$ and overnight at room temperature. Solvent was removed under reduced pressure, and the crude was dissolved in aqueous potassium carbonate $(50 \mathrm{~mL})$. This solution was extracted with $\operatorname{DCM}(3 \times 50 \mathrm{~mL})$. The organic fraction was dried over $\mathrm{MgSO}_{4}$, filtered and the solvent removed under reduced pressure. A colorless oil ( $857 \mathrm{mg}$, 60\% yield) was obtained. Rf $\left(\right.$ Hexanes/AcOEt/TEA 47.5:47.5:5) $=0.2 ;{ }^{1} \mathrm{H}$ NMR $\left(\mathrm{CDCl}_{3}, 400 \mathrm{MHz}\right): \delta 3.16(\mathrm{q}, J=$ 5.9, $\left.2 \mathrm{H}, \mathrm{CO}-\mathrm{NH}-\underline{\mathrm{CH}}_{2}\right) ; 2.79\left(\mathrm{t}, J=5.7,2 \mathrm{H}, \underline{\mathrm{CH}_{2}}-\mathrm{NH}_{2}\right) ; 1.44\left(\mathrm{~s}, 9 \mathrm{H}, \mathrm{CH}_{3}\right) \mathrm{ppm} ;{ }^{13} \mathrm{C}$ NMR $\mathrm{CDCl}_{3}, 100 \mathrm{MHz}$ ): $\delta$ 156.2, 79.2, 43.2, 41.8, 28.4 ppm; ESI MS (positive mode): $m / z: 161.13[\mathrm{M}+\mathrm{H}]^{+} ; \mathrm{M}$ calcd for $\mathrm{C}_{7} \mathrm{H}_{16} \mathrm{~N}_{2} \mathrm{O}_{2} 160.12$.

\section{Acknowledgments}

This work was supported by funds from the Ministerio de Economía y Competitividad (grant CTQ2010-21567-C02-01, and the project RNAREG, grant CSD2009-00080, funded under the programme CONSOLIDER INGENIO 2010), and the Generalitat de Catalunya (2009SGR-208). X. E. was a recipient fellow of the MINECO.

\section{Supporting information}

HPLC Traces of the compounds prepared, commercially available building blocks used for peptide and peptoid assembly, results of the assays carried out with peptides containing Cys(Acm), and ${ }^{1} \mathrm{H}$ - and ${ }^{13} \mathrm{C}-\mathrm{NMR}$ spectra of compounds synthesized according to described procedures. This material is available free of charge via the Internet at http://pubc.acs.org. 


\section{References}

(1) Bock, J. E.; Gavenonis, J.; Kritzer, J. A. ACS Chem. Biol. 2013, 8, 488-499.

(2) Rezai, T.; Bock, J. E.; Zhou, M. V.; Kalyanaraman, C.; Lokey, R. S.; Jacobson, M. P. J. Am. Chem. Soc. 2006, 128, 14073-14080.

(3) Rezai, T.; Yu, B.; Millhauser, G. L.; Jacobson, M. P.; Lokey, R. S. J. Am. Chem. Soc. 2006, 128, 2510-2511.

(4) Boturin, D.; Coll, J.-L.; Garanger, E.; Favrot, M.-C.; Dumy, P. J. Am. Chem. Soc. 2004, 126, 5730-5739.

(5) Birts, C. N.; Nijjar, S. K.; Mardle, C. A.; Hoakwie, F.; Duriez, P. J.; Blaydes, J. P.; Tavassoli, A. Chem. Sci. 2013, 4, 3046-3057.

(6) Zhou, H.; Liu, L.; Huang, J.; Bernard, D.; Karatas, H.; Navarro, A.; Lei, M.; Wang, S. J. Med. Chem. 2013, 56, 1113-1123.

(7) Spurr, I. B.; Birts, C. N.; Cuda, F.; Benkovic, S. J.; Blaydes, J. P.; Tavassoli, A. ChemBioChem 2012, 13, 1628-1634.

(8) Smith, J. W.; Ruggeri, Z. M.; Kunicki, T. J.; Cheresh, D. A. J. Biol. Chem. 1992, $265,12267-12271$.

(9) Gurrath, M.; Müller, G.; Kessler, H.; Aumailley, M.; Timpl, R. Eur. J. Biochem. 1992, 210, 911-921.

(10) Kiptoo, P.; Büyüktimkin, B.; Badawi, A. H.; Stewart, J.; Ridwan, R.; Siahaan, T. J. Clin. Exp. Immunol. 2013, 172, 23-36.

(11) Mulder, G. E.; Kruijtzer, J. A. W.; Liskamp, R. M. J. Chem. Commun., 2012, 48, 10007-10009.

(12) Güell, I.; Vilà, S.; Micaló, L.; Badosa, E.; Montesinos, E.; Planas, M.; Feliu, L. Eur. J. Org. Chem. 2013, 4933-4943. 
(13) Pal, S.; Mitra, K.; Azmi, S.; Ghosh, J. K.; Chakraborty, T. K. Org. Biomol. Chem. 2011, $9,4806-4810$.

(14) Guo, J.; Hu, H.; Zhao, Q.; Wang, T.; Zou, Y.; Yu, S.; Wu, Q.; Guo, Z. ChemMedChem 2012, 7, 1496-1503.

(15) Shirazi, A. N.; Tiwari, R.; Chhikara, B. S.; Mandal, D.; Parang, K. Mol. Pharm. 2013, 10, 488-499.

(16) Chapman, R.; Bouten, P. J. M.; Hoogenboom, R.; Jolliffe, K. A.; Perrier S. Chem. Commun. 2013, 49, 6522-6524.

(17) Chapman, R.; Koh, M. L.; Warr, G. G.; Jolliffe, K. A.; Perrier, S. Chem. Sci. 2013, 4, 2581-2589.

(18) Cai, J.; Rosenzweig, B. A.; Hamilton, A. D. Chem. Eur. J. 2009, 15, 328-332.

(19) Ghosh, P. S.; Hamilton, A. D. J. Am. Chem. Soc. 2012, 134, 13208-13211.

(20) Alam, Md. R.; Ming, X.; Fisher, M.; Lackey, J.; Rajeev, K. G.; Manoharan, M.; Juliano, R. Bioconjugate Chem. 2011, 22, 1673-1681.

(21) Aviñó, A.; Gómara, M. J.; Malakoutikhah, M.; Haro, I.; Eritja, R. Molecules, 2012, $17,13825-13843$.

(22) Elduque, X.; Pedroso, E.; Grandas, A. Org. Lett. 2013, 15, 2038-2041.

(23) Elduque, X; Sánchez, A.; Sharma, K.; Pedroso, E.; Grandas, A. Bioconjugate Chem. 2013, 24, 832-839.

(24) Staros, J. V.; Bayley, H.; Standring, D. N.; Knowles, J. R. Biochem. Biophys. Res. Commun. 1978, 80, 568-572.

(25) Handlon, A. L.; Oppenheimer, N. J. Pharm. Res. 1988, 5, 297-299.

(26) Marchán, V.; Ortega, S.; Pulido, D.; Pedroso, E.; Grandas, A. Nucleic Acids Res. 2006, 34, e24.

(27) Sánchez, A.; Pedroso, E.; Grandas, A. Org. Lett. 2011, 13, 4364-4367. era 24 
(28) Ponsati, B.; Giralt, E.; Andreu, D. Tetrahedron, 1990, 46, 8255-8266.

(29) Zuckermann, R. N.; Kerr, J. M.; Kent, S. B. H.; Moos, W. H. J. Am. Chem. Soc. 1992, 114, 10646-10647.

(30) Ma, B.; Li, G.; Kanter, P.; Lamonica, D.; Grossman, Z.; Pandey, R. K. J. Porphyr. Phthalocyanines 2003, 7, 500-507.

(31) Riva, E.; Comi, D.; Borrelli, S.; Colombo, F.; Danieli, B.; Borlak, J.; Evensen, L.; Lorens, J. B.; Fontana, G.; Gia, O. M.; Dalla Via, L.; Passarella D. Bioorg. Med. Chem. 2010, $18,8660-8668$.

(32) Fauster, K.; Hartl, M.; Santner, T.; Aigner, M.; Kreutz, C.; Bister, K.; Ennifar, E.; Micura, R. ACS Chem. Biol. 2012, 7, 581-589.

(33) Pourceau, G.; Meyer, A.; Vasseur, J.-J.; Morvan, F. J. Org. Chem. 2009, 74, 68376842.

(34) Kiviniemi, A.; Virta, P.; Lönnberg, H. Bioconjugate Chem. 2008, 19, 1726-1734.

(35) Wada, T.; Mochizuki, A.; Higashiya, S.; Tsuruoka, H.; Kawahara, S.; Ishikawa, M.; Sekine, M. Tetrahedron Lett. 2001, 42, 9215-9219.

(36) Coppola, C.; Simeone, L.; De Napoli, L.; Montesarchio, D. Eur. J. Org. Chem. 2011, 1155-1165.

(37) Putta, M. R.; Zhu, F.-G.; Wang, D.; Bhagat, L.; Dai, M.; Kandimalla, E. R.; Agrawal, S. Bioconjugate Chem., 2010, 21, 39-45.

(38) Shen, B.-Q. et al. Nat. Biotechnol., 2012, 30, 184-189.

(39) Monsó, M.; de la Torre, B. G.; Blanco, E.; Moreno, N.; Andreu, D. Bioconjugate Chem. 2013, 24, 578-585. 